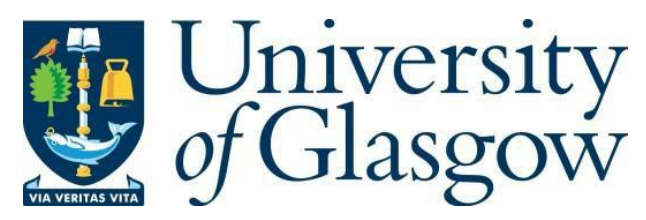

Evans, G. and Neundorf, A. (2018) Core political values and the long-term shaping of partisanship. British Journal of Political Science, 2018

(doi: $\underline{10.1017 / \mathrm{s} 0007123418000339}$ )

There may be differences between this version and the published version. You are advised to consult the publisher's version if you wish to cite from it.

http://eprints.gla.ac.uk/194086/

Deposited on: 2 September 2019

Enlighten - Research publications by members of the University of Glasgow http://eprints.gla.ac.uk 


\section{Highlights of the paper:}

1. Advances our knowledge of the nature of modern political partisanship and the influences on stability and change in party support.

2. Advances knowledge on the impact of a key structuring principle through which people can make sense of the political world - core values

3. Uses high quality data and advanced methods to study the dynamics of partisanship.

4. Helps us to understand dynamics in British party politics. 


\title{
Core Political Values and the Long-Term Shaping of Partisanship in the British Electorate
}

\section{Geoffrey Evans and Anja Neundorf}

\begin{abstract}
Party identification has been thought to provide the central organizing element for political belief systems. We argue in contrast that core values concerning equality and government intervention versus individualism and free enterprise are fundamental orientations that can themselves shape partisanship. We evaluate these arguments in the British case with a validated multiple-item measure of core values, using ordered latent class models to estimate reciprocal effects with partisanship on panel data from the British Household Panel Study, 1991-2007. We demonstrate that core values are more stable than partisanship and have far stronger cross-lagged effects on partisanship than vice versa in both polarized and depolarized political contexts, for younger and older respondents, and for those with differing levels of educational attainment and income, thus demonstrating their general utility as decision-making heuristics.
\end{abstract}

Keywords: Political values, partisanship, panel data, latent class analysis, cross-lagged analysis. 


\section{Introduction}

Since The American Voter it has been argued that voters rely on party identification and impressions about candidate image when deciding how to vote, whilst ideology, values or opinions on specific policies play at most a muted role. There is indeed considerable evidence that partisanship shapes voters' political views. A growing body of studies stemming originally from Campbell et al (1960) and Converse (1964), and re-energized in work by Bartels (2002) and Green et al (2002) demonstrates the centrality of partisanship in shaping issue/policy preferences (Carsey and Layman 2006; Highton and Kam 2011; Milazzo et al 2012), issueproximity (Evans and Andersen 2004), issue salience (Neundorf and Adams 2016), government performance (Evans and Chzhen 2016) and perceptions of the economy (e.g. Anderson et al 2004; Evans and Andersen 2006; Ladner and Wlezien 2007; Chzhen et al 2014). However, partisanship can itself be thought of as endogenous. It seems unlikely that people randomly attach themselves to parties.

In the British context social background attributes such as class were at one time assumed to anchor partisan orientations (Butler and Stokes, 1974; Heath et al 1985), but they have lost their power to shape party preferences in a depolarized party system where relevant choices are no longer provided (Milazzo et al 2012; Evans and Tilley 2012). They thus provide neither strong predictive power nor a mechanism for understanding why people gravitate to different political parties. In recent decades, however, various authors have argued that it is possible to identify core political values that are coherent and stable in which individuals hold fundamental and enduring attitudes towards general moral and political principles like equality (McClosky and Zaller 1984; Feldman 1988; Zaller and Feldman 1992; Sniderman and Piazza 1993; Heath et al. 1994; Evans et al 1996; Ansolabehere et al 2008). It is argued that such values inform preferences across a wide range of specific issues. For Feldman (1988) these enduring core beliefs can account in part for the individual's attitudes towards the more 
transient political issues of the day. This occurs because values provide a heuristic that can be applied to a set of political decisions. As 'cognitive misers' (Fiske and Taylor 2013; Lau and Redlawsk 2001), voters need only assess the relevance of the core value to such decisions rather than drawing upon political attitudes to particular issues on which information is often costly to obtain.

If people hold fundamental and enduring attitudes towards economic and political principles, such as equality, that influence their attitudes towards political issues, it is also likely that these values can shape their partisanship. Such central elements of political belief systems can be expected to influence party preferences as voters update their partisan identities to correspond with their values: if values "predispose us to favor one particular political or religious ideology over another" (Rokeach 1973: 13), it is plausible that they can predispose people to favor one political party over another. Consistent with this idea, when opinions on political issues are measured via multiple indicators of core values they have been shown to have powerful effects on party choice in cross-sectional analyses (e.g. Ansolabehere et al 2008; Bartle 1998; Evans et al 1996; Heath et al 1994).

These observed patterns of association do not in themselves establish whether values influence party choice or vice versa. If someone has a commitment to limited government they are likely to find parties of the right appealing and move in that direction over time, while someone who believes in big government should find parties of the left appealing. Party support should be updated to fit with core values. ${ }^{1}$ Equally, however, partisanship could provide a cue that shifts responses on values over time, with Labour supporters becoming, for example, more

\footnotetext{
${ }^{1}$ The terms 'core values' and 'ideology' can be used interchangeably to denote an overarching or underlying orientation, which summarizes important areas of voters' attitudes towards politics. We use the term "core values" to avoid confusion with the abstract, self-placement measures of "left-right ideology" commonly used in survey studies of electoral behaviour.
} 
pro-redistribution, and Conservative partisans more opposed to redistribution if the parties themselves shift in those directions.

If, as we shall argue, core values are stable aspects of voters political belief systems they should lead to vote switching in response to perceived movements by parties either towards or away from valued goals. Given that perfect equilibrium is unlikely to exist at any point time - electoral politics is not a system preserved in aspic - the tension between core values and party signals provides the incentive to switch from one party to another closer to the core value held by a voter. What we propose is thus not precisely analogous to the thermostatic model (Wlezien 1995; Wlezien and Soroka 2005) of a responsive electorate in which the average expressed policy preference shifts in the opposite direction to government policy. Instead we propose that voters will sort themselves by switching their party preference in response to such party movements. ${ }^{2}$

The only study we know of that examines these dynamics of values and partisanship directly is that of Goren (2005), who examined a range of core principles in a multi-dimensional analysis of US panel surveys and found that partisanship had a stronger influence than core values in cross-lagged models. Goren's analysis suggests that, as in the Michigan model, partisanship is 'the unmoved mover' of values. However, his study is of US voters and previous studies have suggested that partisanship has a stronger influence, at least on policy preferences, in the US than in Britain (Adams et al 2012; Milazzo et al 2012). There is also a long-standing debate on the extent to which partisanship is as distinct from vote preference in Britain as it is in the USA (Butler and Stokes 1974; Heath and Pierce 1992; Sanders and Brynin 1999), which

\footnotetext{
${ }^{2}$ This is not dispute that voters' expressed policy preferences are likely to be influenced by the activities of governments. As a government moves to left, the electorate will probably on average move to the right. The thesis of a moving centre has been advanced fruitfully in the British case by Bartle et al (2011) for understanding election outcomes. However, fundamental to the core values approach is the idea that the stability of voters' core values is likely to be substantially higher than that of their policy preferences. This high level of stability provides a basis for voters changing their parties rather than their values.
} 
could also explain why its relative influence might differ. We return to these issues in the discussion.

In the rest of the paper we develop and test the argument that core values dynamically shape partisanship rather than vice versa. We proceed by first examining the nature of core values in the British context and why these core values are likely to be more influential than partisanship. We also consider the extent of this disproportionate influence across political contexts and for different groups of voters. The empirical analysis examines the association between values and partisanship by following respondents over 16 years across multiple survey waves throughout the 1990s and 2000s and establish which has the stronger effects: core values or party identification. We show that in both polarized and depolarized electoral contexts core values drive partisanship and there is no significant reciprocal effect. Likewise, core values have strong effects on partisanship across the age structure: for both young and old values matter for partisanship, but not vice versa. This pattern also holds across diverse sectors of the electorate: not just among the affluent and highly educated, but amongst those who are typically less-involved in politics, such as the poor and less highly educated. Core values thus appear to provide a generalized decision heuristic that limits preference shaping by parties and can provide a source of political stability or change.

\section{Core values in the British context}

Rokeach (1973: 169) argued that political ideologies are "fundamentally reducible, when stripped to their barest, to opposing value orientations concerning the political desirability or undesirability of freedom and equality in all their ramifications". Consistent with this idea, analyses of attitudes in Britain have repeatedly found that opinions on issues such as income redistribution, government intervention and collective provision of public goods are associated 
along such lines of freedom versus equality. The notion of core beliefs and values has been introduced to make sense of these patterns (Heath et al 1994). These core beliefs are not the same as an over-arching left-right ideology, as views on economic equality typically have little empirical connection with those on social and cultural issues. The latter involve distinct and often conflicting moral principles.

In the period we are examining, and for several decades previously, the axis of division in British politics is very much about redistribution, government intervention and free enterprise. In other words, it is about economic and political equality (Bartle 1998; Bartle and Stimson, 2013; Evans et al 1996; Heath et al 1994; Laver and Budge 1992), ${ }^{3}$ in which "the basic logic of party competition in Britain remained similar to that which held in the $1950 \mathrm{~s}(\ldots)$ a predominantly left-right dimension of competition" (Webb 2004: 39). The Labour Party has generally been the advocate of leftist, redistributive positions, while the Conservative Party has a long-standing reputation for holding more right-wing, free market positions. ${ }^{4}$ These values have been central to British political debate and public responses to it for decades. But are they likely to be shaped by party or vice versa?

Core political values are thought to develop early in the adult life cycle and to persist over time, transcending the influence of short-term political events and party changes. If values are stable there is less room for them to be influenced by partisanship. Conversely, the greater

\footnotetext{
${ }^{3}$ In this respect Heath et al (1994: 119-120) noted that their second dimension of core values (libertarianauthoritarian) is harder to measure and less well-structured as a dimension, as well as being far less strongly predictive of political preferences.

${ }^{4}$ The rise in immigration from the EU in the last decade has made that a matter of concern to many voters, leading to its growing political prominence, its key role in the 2016 EU Referendum and an increase in the political salience of values pertaining to social conservatism. However, the potential for a reduction in levels of EU immigration provided by Brexit and the accompanying sorting of parties and voters occasioned by the Conservatives having firmly grasping the mantle of 'hard Brexit' suggest that redistribution and inequality are unlikely to forgo their central place in political discourse and division, even if other values currently have a magnified political presence (Evans and Menon 2017).
} 
stability of values compared with partisanship should provide a basis for updating partisanship in response to political changes. In other words, influence should run from values to party not vice versa. A first step therefore is to examine the stability of values and partisanship. A second, is to examine whether core political values influence the updating of party identification or vice versa.

Hypothesis 1: (a) core values should be more stable than partisanship, and (b) the crosslagged effects of core values on partisanship should be stronger than vice versa.

In addition to these general hypotheses, we examine potential conditioning influences on the relationship between values and partisanship.

\section{Contextual variation}

In the US, panel-based research on the temporal inter-relationship between political attitudes and partisanship has examined the relationship in varying contexts. Carsey and Layman (2006) look at the effect of issue saliency on the relationship between attitudes and partisanship, showing that issues have more impact when they are salient (c.f. Abramowitz and Saunders 1998). Dancey and Goren (2010) demonstrate the impact of media attention in accentuating the strength of updating between issues and partisanship. While Highton and Kam (2011) find that issue polarization influences the direction of influence in updating beliefs: Issue convergence appears to weaken the effect of issues on partisanship as it strips away the relevance of issue positions to party choice.

In the British case, the main parties ideologically converged in the mid/late 1990s (Budge 1999; Bara and Budge 2001, Bara 2006), as well as converging in their social composition (Heath 2015, 2016). This suggests that the impact of issues on partisanship should 
weaken in a more depolarized context. Milazzo et al (2012) find that the effects of issues on partisanship declined over time as the British party system depolarized. However, most of these studies examine attitudes towards potentially transient political issues of the day rather than underlying values. To the degree that core values are more central elements of political belief systems than partisanship, they should function as heuristics that provide a basis of party choice even when parties are not polarized. Coefficients generally may be of weaker magnitude, but the strength of influence of core values relative to that of partisanship should persist.

Most of the period covered by the BHPS has been characterized by similarity between the main parties in their respective positions on inequality and redistribution, as 'New Labour' muddied the ground between itself and the Conservatives and thus weakened the distinctiveness of their signals to voters (Green 2007; Green and Hobolt 2008; Adams et al 2012). However, the period before 1997 was marked by larger differences between the main parties. The 1997 election represented a step change in perceptions of party convergence (Budge 1999; Bara and Budge 2001; Evans and Tilley 2017). To examine the contextual robustness of the relative impact of values on partisanship we can therefore compare models for the period before the 1997 election with those for 1997 onwards. Although we might expect to see generally weaker effects in the latter, depolarized context, core values should still be relatively more stable and have relatively stronger cross-lagged effects than partisanship.

Hypothesis 2: in both more and less polarized contexts (a) core values should be more stable than partisanship and (b) the cross-lagged effects of core values on partisanship should be stronger than vice versa.

\section{Variation by voter characteristics}


Younger and older voters. Central to an understanding of the relative centrality of values and partisanship to political beliefs is the timing of their emergence in someone's political understanding. If attitudes are well-formed - as indicated by their stability - at an earlier point in adult political socialization they are more likely to influence the adoption of attitudes formed at a later point (Abramson 1979; Jennings 1989; Alwin and Krosnick 1991). If partisanship precedes and influences someone's values we would expect to see evidence of its cognitive presence earlier in the life cycle. If values influence partisanship then we would expect them to stabilize earlier and condition responses to partisan cues.

Hypothesis 3: (a) core values should be more stable than partisanship at an earlier age, and (b) the cross-lagged effects of core values on partisanship should be stronger than vice versa.

More or less educated voters. If core values are widespread and meaningful we would expect them to be consequential for partisanship throughout the electorate. Both 'sophisticated' and 'unsophisticated' voters should hold values independently of partisan cues. So although we could expect the less politically aware to have less stable core values than the more aware (Bartle 2000), those values are still likely to be relatively more stable than, and influential on, partisanship than vice versa. Not only can political sophisticates be expected to bring their partisan attachments into line with their values, so can the politically unsophisticated. We test this by using educational level as a proxy for political sophistication to examine the relative impact of core values and partisanship among politically informed and uninformed voters. ${ }^{5}$

\footnotetext{
${ }^{5}$ This is a particularly interesting test of the relevance of values as partisanship has been argued by some to be a more important heuristic for less politically aware voters who do not want to expend the extensive costs in time and cognitive involvement required to make sense of politics. In comparison with uninformed voters, politically aware citizens are more interested in politics, follow debates, and are more likely to update partisanship in line with their values (Sniderman and Stiglitz 2012; Zaller 1992). On this account, there should be an interaction between level of political sophistication and direction of influence.
} 
Hypothesis 4: The (a) stability and (b) strength of the cross-lagged effects of core values on partisanship will be stronger than vice versa across regardless of level of education.

The rich and the poor. In addition to their appeal to the less politically involved, we might also expect core values that concern, specifically, inequality and redistribution to provide a heuristic that shapes the political preferences of voters across income levels. Income inequality is likely to make these core values relevant to political preference formation via a desire for redistribution by the poor, and endorsement of the free market and opposition to redistribution by the wealthy. Redistribution taps into the concerns of both rich and poor, even if in opposing ways (Meltzer and Richard 1981). It is perhaps not surprising then that analyses using very similar instruments to the core values operationalized here find stable and persisting divisions between income groups on redistribution, even when parties themselves have de-polarized on these issues (Evans and Tilley 2012).

Hypothesis 5: The (a) stability and (b) strength of the cross-lagged effects of core values on partisanship will be stronger than vice versa across levels of income.

\section{Method}

\section{Data}

As we are interested in the long-term relationship between individual's party identification and their core values we use panel data that tracks individual-level changes over an extensive time period. For this we use data from the British Household Panel Study (BHPS), an annual faceto-face, stratified random sample survey of occupants of British households that began in 1991. ${ }^{6}$ Besides numerous questions on the socio-economic status of households and

\footnotetext{
${ }^{6}$ More information on the BHPS is available at: http://www.iser.essex.ac.uk/survey/bhps.
} 
individuals, the BHPS asks respondents' partisanship. The survey also includes a six-item socialist/laissez faire scale of core values developed by Heath et al. (1994) in seven waves between 1991 and $2007 .{ }^{7}$ This extensive time-coverage gives us the opportunity to analyze the individual-level dynamics of core values and party identification across a lengthy period in British politics.

The BHPS contains respondents from England, Scotland, Wales and Northern Ireland, but we restrict our sample to respondents domiciled in England. The 'two-party-plus' system pitting Labour against the Conservatives with the Liberal Democrats as the main minor party operates in pure form only in England. Elsewhere, parties focused on nationalist concerns make the choice set more complex. The number of observations is also reduced for model estimation purposes by only including those respondents that took part in at least three waves. ${ }^{8}$ This leaves 7,582 respondents of which $80 \%$ entered the first wave of the panel in 1991 .

\section{Measuring core political values}

The labels 'left' and 'right' (or 'liberal' and 'conservative') can be employed as shortcuts that help citizens connect their underlying ideological/value predisposition to specific policy preferences (Inglehart and Klingemann 1976; Fuchs and Klingemann 1989). Similarly, political parties and commentators use these labels to describe whole packages of policies (Budge et al. 2001; Klingemann et al 2006). However, it is unclear how respondents interpret such labels, so we do not measure them by asking people whether they are 'left-wing' or 'right-

\footnotetext{
7 The years in which the battery of questions was included are 1991, 1993, 1995, 1997, 2000, 2004, and 2007. Waves in which the values items were not asked were excluded from the analysis.

${ }^{8}$ Some $46 \%$ of our respondents took part in all seven waves in which the ideology items were asked. Another $19 \%$ only missed one wave. Less than $10 \%$ of the respondents in our final model have only three valid responses. The model can be viewed as a hierarchical setup with responses nested within individuals. Missing responses mean less information per individual, but maximum likelihood estimates are still consistent.
} 
wing, ${ }^{9}$, but instead use six observed indicators that refer to examples of either a left or rightwing value position. In this we follow, for example, Ansolabehere et al. (2008) who use multiple survey items to measure latent dimensions of values and beliefs, and demonstrate their predictive validity for vote choice in U.S. Presidential (Ansolabehere et al 2008) and Congressional elections (Ansolabehere et al 2006).

Heath and his colleagues (1994) developed and validated a scale to measure core values by drawing up a list of items designed to cover the main theoretical components of the core 'socialist versus laissez faire' value domain. ${ }^{10}$ To measure socialist/laissez-faire values they designed items to tap into collectivism and individualism, government intervention and free enterprise, and economic and political equality. These items were asked in an agree/disagree format with five response categories. Since the aim was to design scales that could be used over a period of many years, the items did not address topical policy issues, but were framed as questions about general principles that could be asked in future studies when the specific political issues of the day might have changed. Most items were designed specifically for the scale. The items in the final six-item, core values scale were obtained via an item selection procedure designed to tap into collectivism and individualism, government intervention and free enterprise, and economic and political equality while maintaining acceptable levels of inter-item reliability. This scale was consequently included in multiple waves of the BHPS, where respondents were asked whether they agreed or disagreed (strongly agree 1; agree 2, neither agree nor disagree 3 ; disagree 4 ; strongly disagree 5$)^{11}$ with the following statements:

\footnotetext{
${ }^{9}$ Heath et al (1994) demonstrated that left-right self-placement had lower levels of stability and weaker predictive validity than the core values scale, especially among less educated respondents.

${ }^{10}$ Heath et al (1994) also developed a libertarian-authoritarian values scale. However, because of the relatively minor political importance of libertarian-authoritarian values in the years covered by the BHPS, it did not include the scale in any of its waves.

${ }^{11}$ Answers were coded so that 1 equals the most left-wing, and 5 the most right-wing response. Exploratory factor analysis confirms they load on only one factor. The items have a Cronbach's alpha of 0.65 , indicating a reasonably high degree of inter-item correlation.
} 

A: Ordinary people get their fair share of the nation's wealth (reversed)
B: Major public services and industries ought to be in state ownership
$\mathrm{C}$ : There is one law for the rich and one for the poor
D: Private enterprise is the best way to solve Britain's economic problems (reversed)
E: It is Government's responsibility to provide a job for everyone who wants one
F: Strong trade unions are needed to protect employees working conditions and wages

\section{Measuring party identification}

In each wave respondents receive the following question battery: "Generally speaking, do you think of yourself as a supporter of any one political party?" Respondents who answer "yes" are asked "which one". Respondents who answer "no" are asked two follow-up questions that first ask if they think of themselves as "a little closer to one political party than to the others." If they still reply "no", they are asked "if there was a General Election tomorrow, which political party do you think you would be most likely to support." In keeping with much of the literature (Green and Palmquist 1990, 1994; Green et al. 2002), we only consider as partisans those who responded "yes" to the first two questions, excluding respondents who only express support for a party in the event of an election. At each time point, respondents are assigned to the following: (1) Labour; (2) Conservative; or (3) not supporting any of the major parties. This latter category includes $43 \%$ of the respondents: $9 \%$ identify with the Liberal Democrats; $1 \%$ with any of the other smaller parties; and 33\% have no party identity. As shown in Appendix 1, analyses distinguishing Liberal Democrats produce substantively the same results.

\section{Measurement of conditioning variables and controls}

Numerous analyses of British Election Survey data (cf. Butler and Stokes 1974; Heath et al 1991; Heath et al 1994; Evans et al 1996) suggest that a range of socio-demographic 
characteristics are important for capturing individual differences in both party support and values, and we model partisanship and values as a function of these observed individual attributes. Age is coded as categorical, dividing respondents into six categories (15-24, 25-34, $35-44,45-54,55-64,65+)$ to allow comparison of effects across age groups. Income is measured as total individual annual income from wages and transfers. We use income quintiles for each panel wave, dividing the respondents in five groups from bottom to top- $20 \%$ annual income. ${ }^{12}$ Education is coded as respondent's highest qualification achieved. We recoded the original 13-category variable to a six-category education variable with the following highest qualifications: 1. no qualifications, 2. less than O-levels, 3. O-levels, 4. A-levels, 5. other degree (e.g. teaching or nursing) and 6. university degree. Other socio-demographic controls included in the BHPS include gender, social class and housing status. Social class is measured using the European Socio-economic classification (Rose and Harrison 2010). Besides using detailed occupational codes (based on ISCO88), it uses an individual's supervisory status and (for employers) number of employees to determine class positions. Housing status distinguishes between homeowners, mortgage holders, private renters, and those in social housing.

\section{Analysis}

Although political values can be thought of as lying on a continuum, typically measured via additive Likert scales, we focus our primary analysis on their qualitative character. It is common to talk of left versus right and these constructs are likely to cluster responses to individual items accordingly. In the same way as we can examine whether people update their

\footnotetext{
${ }^{12}$ We use the imputed income data provided by the BHPS. For more information on the income variables and the imputation process see Jenkins (2011), chapter 4.
} 
partisanship by, for example, moving from being a Labour to a Conservative partisan, we can examine whether people move from being left-wing to being right-wing in their value positions from one time point to the next. Since we also treat choice of party as nominal and are primarily interested in switching between left and right-wing political choices this approach allows direct comparisons of the strength of effects of values on partisanship. For the cross-lagged analysis, in particular, this degree of measurement equivalence provides important information for interpreting the relative strength of their effects.

For this purpose we use latent class analysis (LCA). LCA is a categorical data reduction method analogous to factor analysis. ${ }^{13}$ The main feature of LCA is the ability to investigate relationships among categorical or ordinal variables assuming local independence between these indicators. This can be undertaken for the six values items to reveal their latent structure, and also for the partisanship measure. Numerous previous analyses of the dynamics of party identification have found measurement error to be endemic (e.g. Green and Palmquist 1990, 1994; Green et al. 2002). We can therefore specify 'true' partisan identification as a latent variable measured imperfectly by observed individual choices. This results in a single-indicator latent variable model where partisan identification, the indicator, is measured on multiple occasions (Skrondal and Rabe-Hesketh 2004). ${ }^{14}$

\section{LCA estimation}

Our latent class model of the latent value position of respondent $i \delta_{i}$ can be expressed as (see McCutcheon 1987; Skrondal and Rabe-Hesketh 2004):

\footnotetext{
13 The appropriateness of the LCA method is also suggested by tests conducted during the development of the items. When the scale was divided arbitrarily into three broad categories, the associations between the scale and other variables were more or less unaffected (Heath et al. 1994: 127).

${ }^{14}$ As well as estimating the relationship between latent classes for the values scales and those for partisan identification, we include further analyses using linear Structural Equation Modeling (SEM) estimation as robustness checks in Appendix 2.
} 


$$
\delta_{i}=P\left(\boldsymbol{y}_{i}\right)=\sum_{c=1}^{3} \pi_{i c} \prod_{j=1}^{6} P\left(y_{i j} \mid c\right)
$$

where $P\left(\boldsymbol{y}_{i}\right)$ is the probability of a specific observed response pattern of the six indicator variables $j \boldsymbol{y}_{i}=\left(y_{1 i}, \ldots, y_{6 i}\right) . \pi_{j c}$ represents the probability of respondent $i$ being in one of the discrete latent classes $\mathrm{C}(\mathrm{c}=1,2,3)$, and the local independence assumption is met by $P\left(\boldsymbol{y}_{i}\right)$, as the specific response to each single survey item by each respondent $\left(y_{i j}\right)$ solely depends on the latent class a respondent is classified into once measurement error is taken into account. ${ }^{15}$ Each of our six indicators is linked to the latent value $\delta_{i}$ via conditional probabilities, which are comparable to factor loadings in a factor analysis. The conditional probabilities of the model and the distributions of the three latent classes - leftist, centrist and rightist - on the six-item additive index score are reported in Appendix 3, which also presents further information on the LCA analysis. The latent classes distinguish the value positions very effectively. For example, 94\% of respondent who were classified as left agreed that 'public services ought to be state owned', while $63 \%$ of those classified as right disagreed with this statement. The remaining items have similar conditional probabilities depending on the classification of respondents. The modal category for each classification is always correct.

Table 1 presents the mean distribution of political values across these three different classes. It can be seen that $58 \%$ of the respondents of the BHPS are classified as centrist, about $20 \%$ have coherent leftist values, and $22 \%$ rightist political values. Table 1 also reports the proportion of party identifiers in each of the latent classes. It shows that the values classification

\footnotetext{
${ }^{15}$ As we cannot directly observe the values of a person, we need to utilize manifest or observed variables that help us to approximate the 'true' political belief. However, these indicator variables $y_{j}$ do not perfectly reflect the underlying latent variable they are supposed to measure. Hence, responses to these will have some measurement error, an expected mean of zero, and are uncorrelated with each other and the latent variable.
} 
is able to distinguish the partisanship of each class very effectively. The modal category of each latent class is as expected. For example, $58 \%$ of leftists are also Labour partisans, while only 5\% support the Conservative party. The clear ideological distinction of partisans is also obvious for those with right-wing values. Those classified as centrist are most likely not to have a party identification or to support a smaller party.

Table 1: Latent values and partisanship (in \%)

\begin{tabular}{lccc}
\hline & & \multicolumn{2}{c}{ Core values: } \\
& Classification \\
& Centrist & Leftist & Rightist \\
\cline { 2 - 4 } Estimated proportion & 58 & 20 & 22 \\
Observed party identification (PID) & & & \\
No/other PID & 52 & 37 & 28 \\
Labour & 27 & 58 & 05 \\
Tories & 20 & 05 & 66 \\
\hline
\end{tabular}

\section{Modeling the dynamics of partisanship and values}

We use cross-lagged models to analyze the dynamics of partisanship and values. These allow us to simultaneously estimate 1) the effect of previous partisanship on current values, while controlling for previous values and 2) the effect of previous value positions on partisanship, while controlling for previous partisanship. As we employ discrete categories - leftist versus rightist values, Labour versus Conservative partisanship - we use maximum likelihood estimation in a series of multi-nominal logit models. The final cross-lagged model of values and partisanship (both treated as categorical latent variables) can be summarized as follows:

$$
\begin{aligned}
P\left(P I D_{i} \mid \boldsymbol{y}_{i}, \boldsymbol{x}_{i}\right) & =\sum_{\theta_{o}=1}^{T} \ldots \sum_{\theta_{T}=1}^{T} P\left(\theta_{0} \mid \boldsymbol{x}_{i 0}\right) \sum_{t=1}^{T} P\left(\theta_{t} \mid \theta_{t-1}\right) \sum_{t=1}^{T} P\left(\theta_{t} \mid \delta_{t-1}\right) \sum_{t=1}^{T} P\left(P I D_{i t} \mid \theta_{t}\right)
\end{aligned}
$$




$$
\begin{aligned}
P\left(\boldsymbol{y}_{i} \mid P I D_{i}, \boldsymbol{x}_{i}\right) & =\sum_{\delta_{o}=1}^{T} \ldots \sum_{\delta_{T}=1}^{T} P\left(\delta_{0} \mid \boldsymbol{x}_{i 0}\right) \sum_{t=1}^{T} P\left(\delta_{t} \mid \delta_{t-1}\right) \sum_{t=1}^{T} P\left(\delta_{t} \mid \theta_{t-1}\right) \sum_{t=1}^{T} P\left(P I D_{i t} \mid \theta_{t}\right)
\end{aligned}
$$

whereas $P I D_{i}$ in model (2) is the observed party identification of respondent $i$, which is conditioned on the observed response pattern of the six value position indicators $j \boldsymbol{y}_{i}=\left(y_{1 i}, \ldots\right.$, $y_{6 i}$ ) and covariates $\boldsymbol{x}_{\boldsymbol{i}, \mathbf{0}}$ on the initial state of partisanship. This model specifies the nominal level variable measuring latent party support $\theta_{i, t}$, to be a function of partisanship as reported by the BHPS respondent $P I D_{i t}$ and a level of measurement error that is assumed to be time invariant for reasons of identification $\left(P\left(P I D_{i t} \mid \theta_{t}\right)\right)$. The value position of a respondent $i$ is measured by the latent variable $\delta_{i t}$, described in model (1) above. The central parts of model (2) and (3) are the transition probabilities (partisanship: $P\left(\theta_{t} \mid \theta_{t-1}\right)$; values: $P\left(\delta_{t} \mid \delta_{t-1}\right)$ ) that account for the stability of our two dependent variables and most importantly the estimated cross-lagged effects of values on partisanship $\left(P\left(\theta_{t} \mid \delta_{t-1}\right)\right)$ and partisanship on values $\left(P\left(\delta_{t} \mid \theta_{t-1}\right)\right)$. As the models show, we control for relevant covariates $\boldsymbol{x}_{i 0}$ predicting a person's (latent) partisanship $\left(\theta_{0}\right)$ and values $\left(\delta_{0}\right)$ when they first enter the panel.

\section{Results}

\section{The dynamics of partisanship and core values}


First we examine and compare the levels of stability of partisanship and core values, testing Hypothesis 1 (a). Models estimating these coefficients are presented in Table 2. These use effect coding which, unlike dummy-coding, uses ones, zeros and minus ones to convey all of the necessary information on group membership (e.g. party support and core values). This allows us to directly compare the effects of all categories rather than having to set one of the categories to be the reference point. In this model, both latent variables are dependent (at time t) and independent variables (at time t-1) simultaneously.

Table 2: Cross-lagged models: Estimates of transition probabilities

\begin{tabular}{|c|c|c|c|c|c|c|}
\hline \multirow{2}{*}{$\begin{array}{l}D V=\text { Core } \\
\text { values }\end{array}$} & \multicolumn{2}{|c|}{ Rightist } & \multicolumn{2}{|c|}{ Centrist } & \multicolumn{2}{|c|}{ Leftist } \\
\hline & coef. & s.e. & coef. & s.e. & coef. & s.e. \\
\hline Intercept & $-0.89 * * *$ & 0.27 & $1.69 * * *$ & 0.22 & $-0.79 *$ & 0.39 \\
\hline \multicolumn{7}{|l|}{$\underline{\text { Cross-lagged effects }}$} \\
\hline Conservative(t-1) & -0.06 & 0.10 & $0.17^{* *}$ & 0.06 & -0.11 & 0.09 \\
\hline No/oth PID (t-1) & -0.07 & 0.08 & -0.06 & 0.05 & $0.13 *$ & 0.06 \\
\hline Labour(t-1) & 0.13 & 0.11 & -0.11 & 0.06 & -0.02 & 0.08 \\
\hline \multicolumn{7}{|l|}{$\underline{\text { Stability coefficients }}$} \\
\hline Rightist (t-1) & $4.47^{* * *}$ & 0.44 & $-0.90 *$ & 0.41 & $-3.57 * * *$ & 0.79 \\
\hline Centrist (t-1) & $-0.94 * *$ & 0.29 & $1.26 * * *$ & 0.23 & -0.32 & 0.41 \\
\hline Leftist ( $t-1)$ & $-3.53 * * *$ & 0.45 & -0.36 & 0.28 & $3.89 * * *$ & 0.44 \\
\hline \multirow[t]{2}{*}{ DV = Partisanship } & \multicolumn{2}{|c|}{ Tories } & \multicolumn{2}{|c|}{ No/oth PID } & \multicolumn{2}{|c|}{ Labour } \\
\hline & coef. & s.e. & coef. & s.e. & coef. & s.e. \\
\hline Intercept & $-0.61 * * *$ & 0.06 & $0.72 * * *$ & 0.04 & $-0.11 * *$ & 0.04 \\
\hline \multicolumn{7}{|l|}{$\underline{\text { Cross-lagged effects }}$} \\
\hline Rightist (t-1) & $0.80 * * *$ & 0.05 & $-0.11 * *$ & 0.04 & $-0.69 * * *$ & 0.06 \\
\hline Centrist (t-1) & $-0.10 *$ & 0.04 & 0.01 & 0.03 & $0.09 *$ & 0.04 \\
\hline Leftist ( $t-1)$ & $-0.71 * * *$ & 0.07 & $0.11 * *$ & 0.04 & $0.60 * * *$ & 0.05 \\
\hline \multicolumn{7}{|l|}{$\underline{\text { Stability coefficients }}$} \\
\hline Tories (t-1) & $2.48 * * *$ & 0.06 & $-0.62 * * *$ & 0.05 & $-1.86 * * *$ & 0.07 \\
\hline No/oth PID (t-1) & $-0.66 * * *$ & 0.07 & $1.31 * * *$ & 0.05 & $-0.65 * * *$ & 0.05 \\
\hline
\end{tabular}




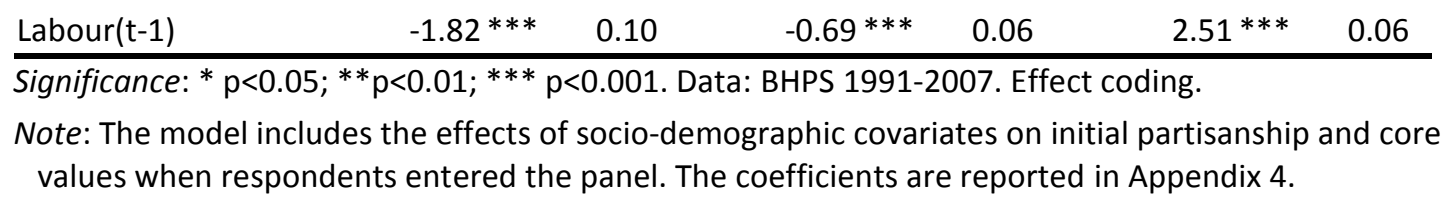

The stability coefficients are shown in the top half of Table 2 . These are the lagged effect of partisanship on current partisanship and the lagged effect of core values on current values. We find that consistent with Hypothesis 1(a), values are about twice as stable as partisanship.

Table 2 also displays the cross-lagged effects on the updating of the two dependent variables. With the exception of two cases, party identification does not affect core values, whereas as predicted in hypothesis 1(b) core values have strong, consistent and significant effects on changes in partisanship. The direction is as expected: Right-wing respondents are more likely to identify with the Conservatives in the next wave and less likely to identify with Labour, and vice versa.

\section{Core political values and partisanship in polarized and depolarized contexts}

To test whether these results are consistent across political contexts we split the panel into two periods. The first period includes three panel waves from 1991-1995 and covers the Conservative government. The second time period includes the four panel waves between 1997-2007 when 'New' Labour was in government and the two main parties converged ideologically, whether measured using manifesto data (i.e. Budge 1999; Bara and Budge 2001; Bara 2006), expert surveys (Rehm and O’Reilly 2010); or public perceptions (Evans and Tilley 2017).

The findings are summarized in Figure 1, which graphically plots logit coefficients and corresponding $95 \%$ confidence intervals of stability and cross-lagged models for the earlier (black bars) and later periods (grey bars). ${ }^{16}$ The two panels on the left plot the cross-lagged

\footnotetext{
${ }^{16}$ The corresponding numerical results can be found in Appendix 5.
} 
effects, comparing the size of the effect for the two periods for core values (upper panel) and partisanship (lower panel), while the panels on the right plot the stability coefficients for core values (upper panel) and partisanship (lower panel). For this and following figures we use different scales to more easily compare stability coefficients and cross-lagged effects, as the former are much larger than the latter.

The top-left panel of Figure 1 shows that partisanship does not affect core values. This is the case in both more (1991-95, black bars) and less polarized periods (1997-2007, grey bars). However, the lower-left panel reveals a clear difference between the two periods. In the more polarized context the effects are significantly stronger. For example, in the New Labour era characterized by depolarization, the effect of being leftist on subsequent Labour

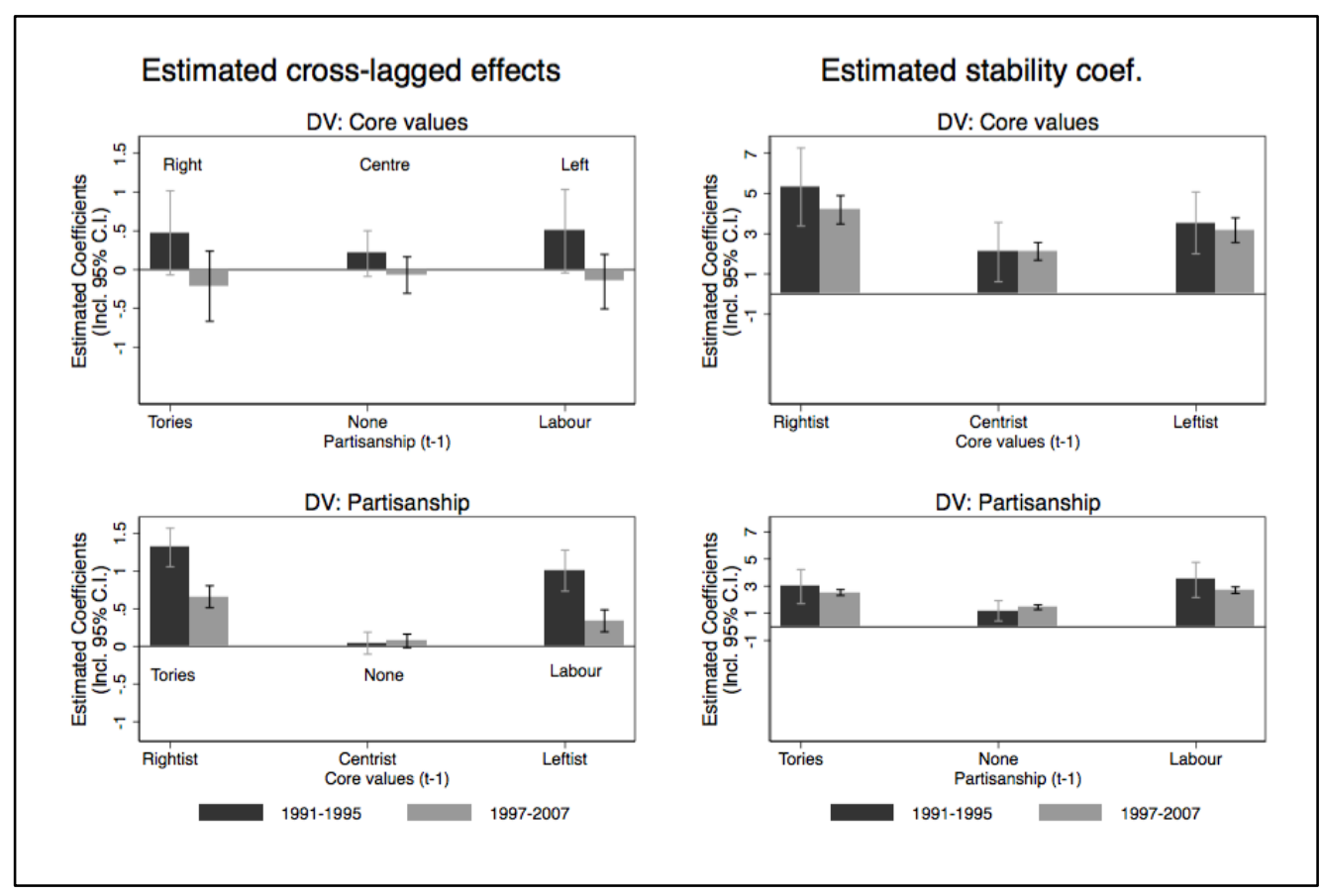

Figure 1: Cross-lagged models: estimates on transition probabilities of ideological and partisan consistent responses (incl. 95\% c.i.). For full results see Appendix 5. 
support is only $b=0.34(p<0.001)$, whereas the effects of leftist values were three times as strong during the 1991-1995 period $(b=1.01, \mathrm{p}<0.001)$. Similarly, the lagged effect of right-wing core values on support for the Conservatives halved between the 1991-1995 $(b=1.30, p<0.001)$ and 1997-2007 periods $(b=0.66, p<0.001)$. In contrast, we find no significant differences in the stability of either core values or partisanship between the two periods.

\section{Sources of heterogeneity: Core values and partisanship across age, education and income}

We next conditioned the stability and cross-lagged estimates by age. The results are summarized in Figure 2, which shows that core values drive partisanship to a much greater extent than vice versa across all age groups. The cross-lagged effects of party identification on core values are jointly not even significant (Wald-test (df): 32.4 (24)). Strikingly, the stability coefficients of core values are also very similar across all age groups, which suggests that core values do indeed develop early in life and remain stable thereafter. In contrast, the

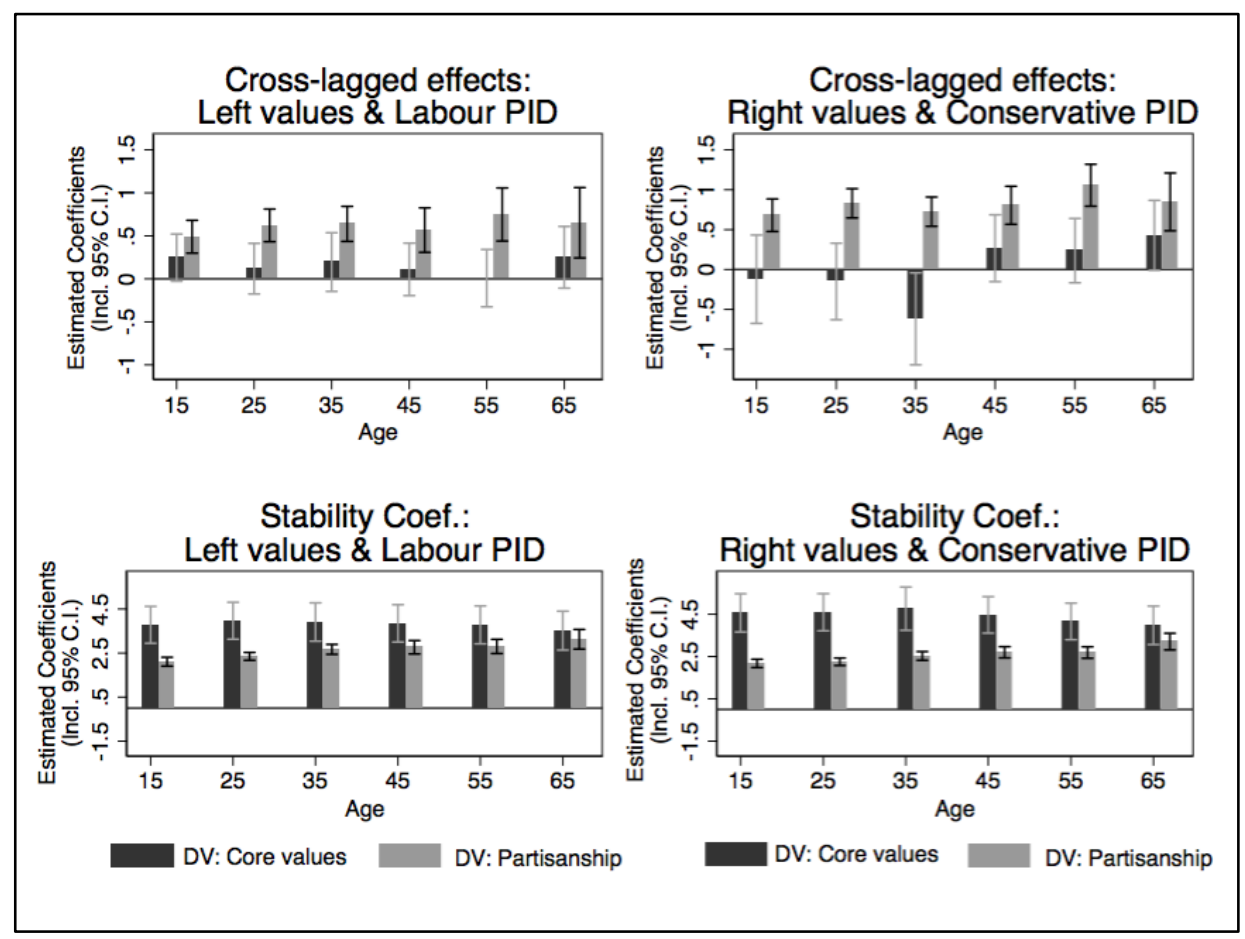

Figure 2: Cross-lagged interactions and stability coefficients conditioned on age (incl. 95\% c.i.). (For full results see Appendix 6.) 
figure shows the well-documented pattern of increasing partisanship stability with age from a relatively low starting point. We see for example, the stability coefficient in Labour support increases from $b=2.11(p<0.001)$ among 15-24 year olds to $b=3.13(p<0.001)$ among those 65 and older. However, with the sole exception of these respondents aged 65 and over, core values are significantly more stable than partisanship.

Finally, looking at the results for the associations between right values and Conservative partisanship and left values and Labour partisanship for educational position and income, we again see familiar patterns. Figure 3 confirms that the cross-lagged impact runs from core values to partisanship in all education levels: e.g. right-wing respondents are more likely to support the Conservative party in the next panel wave. The cross-lagged effects of partisanship on values are insignificant for all educational levels except those with less than 'O' levels, for whom the effect of Labour partisanship on values just reaches significance.

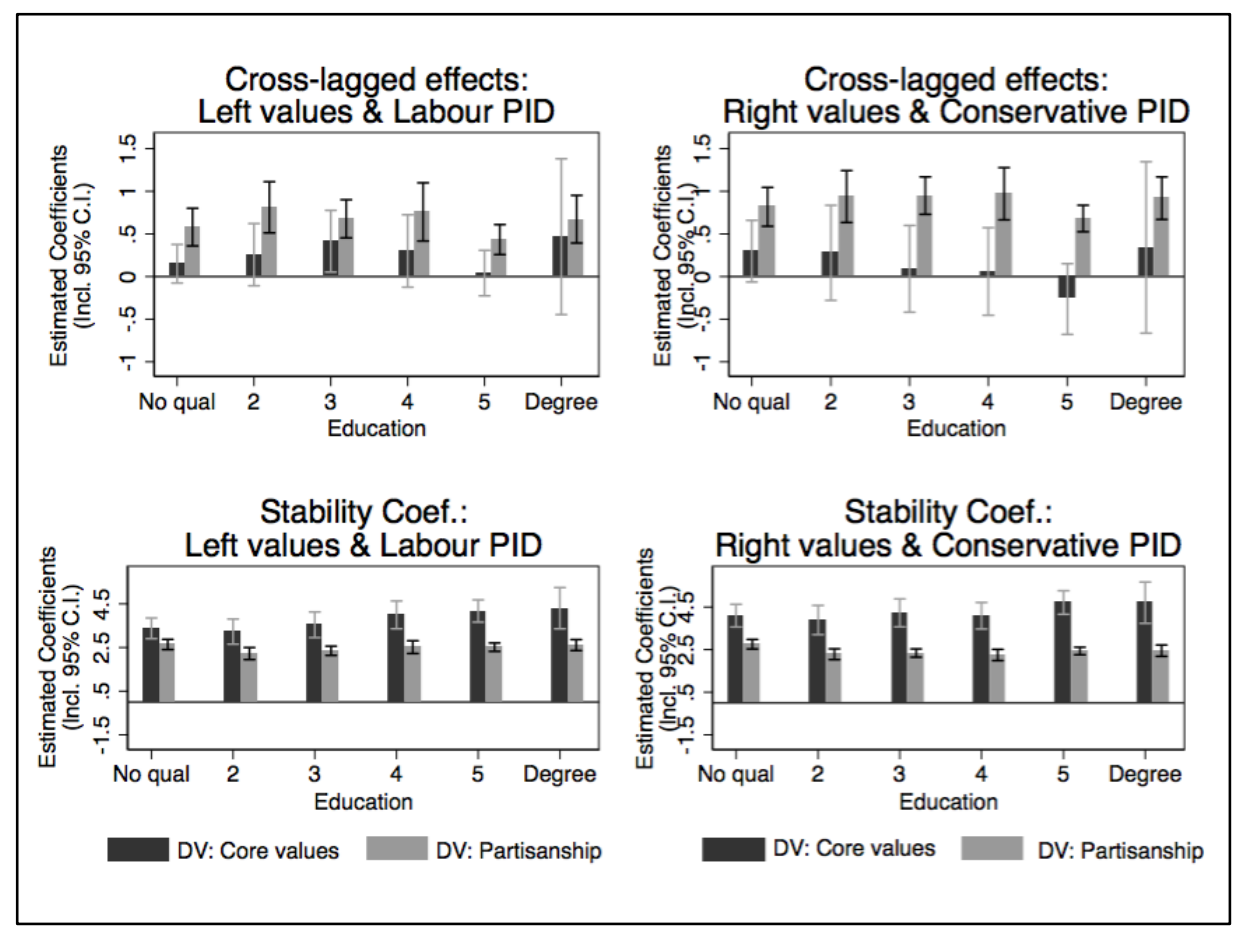

Figure 3: Cross-lagged interactions and stability coefficients conditioned on education level (incl. 95\% c.i.). (For full results see Appendix 7.) 
As expected (e.g. Bartle 2000), the stability coefficients (reported in the lower panels) of political values are weaker for less highly educated respondents. For example, the stability coefficient for leftist respondents is 4.32 for the highly educated and 3.21 for those with only primary education. However, even among primary-educated respondents the stability of values is higher than the stability of partisanship among the most highly educated respondents.

Looking finally at income (Figure 4), we again see that party identification does not affect values, regardless of respondents' level of income, whereas values consistently affect partisanship across all income levels on both left and the right, for Labour and the Conservatives respectively. We find only one significant effect of partisanship on values: Labour respondents in the $20-40 \%$ quintile are less likely to be leftist. All other effects of partisanship on core values are insignificant.

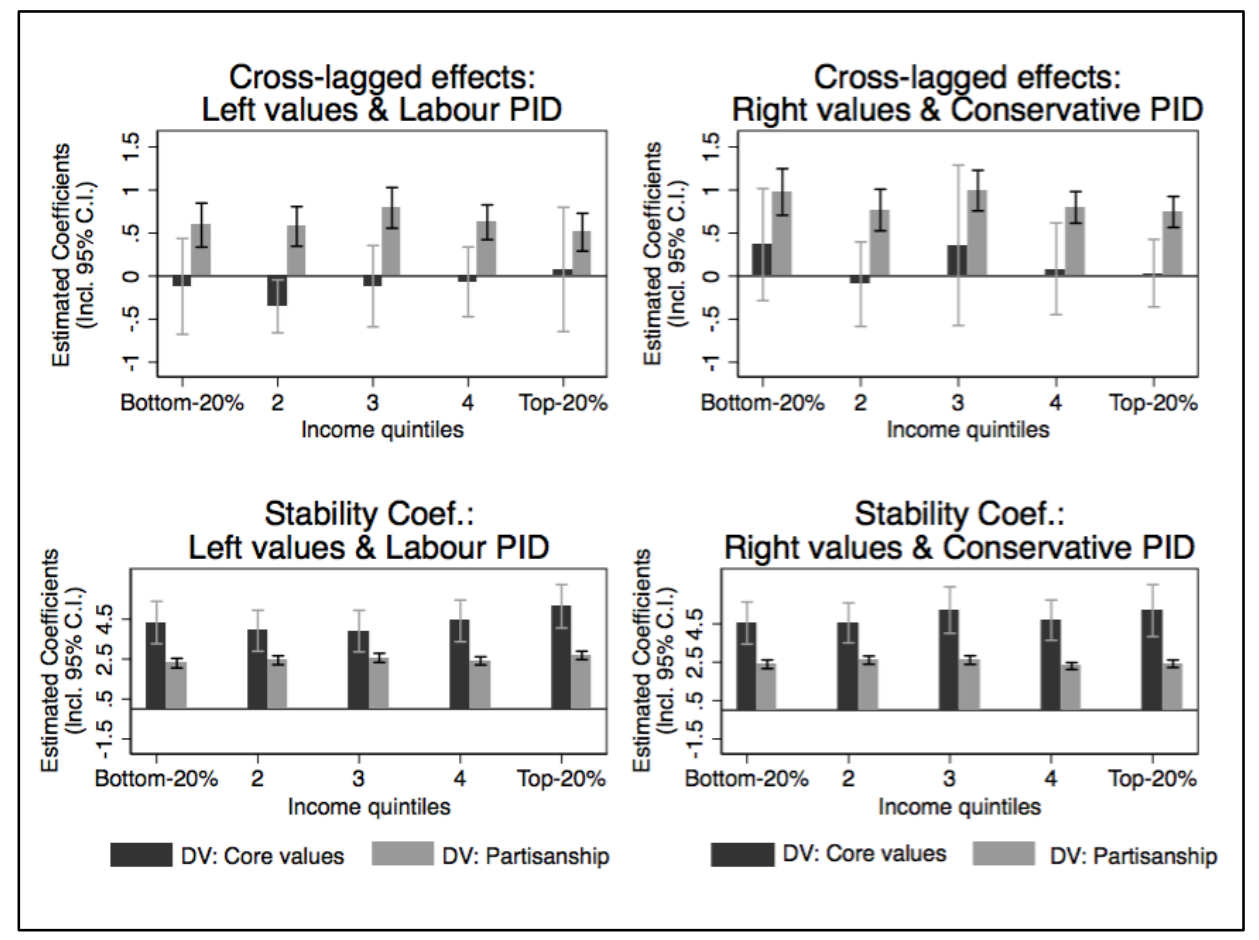

Figure 4: Cross-lagged interactions and stability coefficients conditioned on income quintiles (incl. 95\% c.i.). (For full results see Appendix 8.) 
The stability coefficients reported in the two lower panels also show that on both left and right core values are significantly more stable than partisanship across the full range of income quintiles. Even the lowest level of stability for core values is substantially higher than that obtained for the highest level of partisan stability. It is also worth noting that there is no clear decrease or increase in effect strength with changing income.

\section{Conclusions}

This study advances our knowledge of the influences on stability and change in partisanship. It also advances our understanding of a key structuring principle through which people make sense of the political world - core values. The use of unusually long-term and high quality survey data to study the dynamics of values and partisanship adds strength to these claims. Ultimately, they help us to understand current dynamics in British party politics.

To elaborate on these points, our analysis provides powerful evidence that over the long-term values shape partisanship rather than vice versa. We draw this conclusion from cross-lagged analyses, which find that core values are more stable than partisanship and have a substantially stronger lagged influence on partisanship than vice versa. In 'Conversian' terminology, we infer that core values are more central elements of political belief systems than is partisanship. Because of the size and scope of the BHPS these analyses are able to range across a 16 year period in which British politics changed considerably, establishing that the impact of values was predominant over that of partisanship in both relatively polarized and depolarized contexts. This pattern also holds for young and old, more or less educated, and rich and poor respondents. That core values are as stable amongst those aged 15-24 as they were amongst older age groups is particularly informative regarding the likely timing of their consolidation in political belief systems when compared with the later stabilization of partisanship. 
The extent and quality of the panel data and the measurement of the key construct give us some confidence in these findings. However, the use of latent class analysis (LCA) was also important as it facilitated equivalence in the measurement of the key constructs of core values and partisanship by estimating them as latent classes. This enabled comparison of the crosslagged effects as well as the stability of our instruments. By doing so, we controlled for the potential artifact of comparing a larger range of scores derived from a standard scale with a smaller one obtained from typical partisanship measures. Given this, what then can we infer with respect to the implications of relationship between partisanship and values in Britain and elsewhere?

Firstly, we shall consider how core values help us to understand current dynamics in British politics. Core values appear to differ from many other political perceptions and attitudes that, as mentioned in the introduction, have been shown to be more strongly conditioned by partisanship than vice versa. ${ }^{17}$ One key implication of this centrality of values within voters' political belief systems is a resistance to political 'preference shaping' by parties. Parties simply cannot 'lead' their supporters. As recently noted: "non-convergence of the British public's policy beliefs has an important implication for parties' election strategies: namely, that the electoral "market" for clearly left- and right-wing social welfare policies today has not changed markedly over the past twenty years" (Adams, et al 2012: 510; see also Baldassarri and Gelman 2008). Core values prevent parties transforming the electorate into a mirror of their own positions. Instead, voters constrain parties. Moreover, the broad nature of these findings across diverse sectors of the electorate - not just among the rich and highly educated

\footnotetext{
${ }^{17}$ Interestingly Milazzo et al (2012) find that “the influence of British citizens' policy viewpoints on their party attachments is stronger - and the effect of British citizens' party attachments on their policy beliefs is weakerthan it is in the United States". They interpret this in terms of the higher levels of polarization between the US parties, which may well be the case with respect to policy preferences. However, our evidence suggests that in Britain core values are more influential than partisanship even in the somewhat more polarized era of the early 1990s.
} 
but among the poor and those with little formal education - could put pressure on parties to represent the preferences of these otherwise potentially marginalized groups, depending on the electoral system and the presence of challenger parties. ${ }^{18}$

So, for example, although Labour moved to a more centrist position on both redistributive and social issues from the 1990s onwards, their traditional supporters working class did not, leaving the latter relatively unrepresented and 'up for grabs' electorally (Evans and Tilley 2017). The main consequence of this increasing value discrepancy between the party and its traditional voters was an increase in non-voting amongst poorer voters and those with low levels of formal education. A secondary consequence, as Evans and Mellon (2016) illustrate using BES panel data, was the failure of the political left to carry its traditional supporters with it as it moved to more liberal positions on social issues such as immigration and the EU (Ford and Goodwin 2014). This in turn led to defection over the period from 20052015 as voters switched to other parties, primarily UKIP, rather than adjust their core values to fit with those of the Labour Party.

Core values can also help us to understand current political events such as the outcome of the recent EU Referendum. If the electorate's preferences are less mutable by parties and partisanship than has sometimes been assumed, then despite all of the political parties - with the obvious exception of UKIP - being pro-Remain, many of their partisans chose not vote with them. To a substantial degree, even the partisans of the pro-Remain parties in the EU Referendum failed to comply with the choice the parties advocated (Curtice 2016).

\footnotetext{
${ }^{18}$ In this sense, Britain can be thought to have value-based pressures for a broader, more egalitarian form of political representation than the US. Researchers such as Gilens (2005) and Bartels (2008) have argued that US politicians respond disproportionately to the preferences of affluent and educated voters in part because they believe these voters are more responsive to policies than are the poor and less highly educated. The potential for egalitarian representativeness depends for its effectiveness however on such voters having credible alternatives, which can be hard to establish in a majoritarian system.
} 
The explanatory power of core values is apparent - even if not necessarily the ones examined in this study. We are left, however, with the question of why our findings differ from those of Goren, whose path-breaking study indicated that partisanship is the primary driver of values rather than the reverse. There are several possible answers. Firstly, Goren's analysis was undertaken with US respondents. Over the years, various scholars have suggested that responses to questions on partisan identity have different meanings in the USA and Britain. Butler and Stokes (1969: 43) famously stated that 'the British voter is less likely than the American to make a distinction between his current electoral choice and a more general partisan disposition'. The assumption being that in Britain the two instruments are more likely to be measuring expressions of the same thing - party preference (Brynin and Sanders, 1993; Sanders and Brynin, 1999). ${ }^{19}$ If in the USA partisanship is more clearly distinct from vote choice, it is in a sense perhaps more 'real' as an independent element of political cognition. As such, it is likely to be more exogenous. In contrast, to the degree that British party preference is less distinguishable from vote intention, there is more room for an alternative 'unmoved mover' of party preference - i.e. core values.

There is also a second possibility. Goren's analysis was undertaken using the ANES panel study of 1992-94-96, a relatively short period covering just the $1^{\text {st }}$ Clinton Administration. This finding might not still hold given the politicization of social values that has occurred in the 25 or so years since. It is tempting to imagine that Trump's recent US presidential election victory might represent a historic example of the supremacy of values over partisanship, much as we have suggested was the case with Brexit. A re-analysis of the impact of core values in the US could be timely.

\footnotetext{
${ }^{19}$ Though, as Bartle (2001) has noted, this could also be an artefact resulting from differences in the way that party identity is measured in the two countries.
} 
We need to keep in mind of course that this paper is only a first step at providing British evidence of the impact of values on partisan switching. It covers a specific time period and only includes core values concerning inequality and redistribution. An important area for future analysis lies in the conditionality of the extent of the influence of core values vis-a-vis partisanship. It is possible for example that the well-known decline in the strength party identification in the final third of the $20^{\text {th }}$ century, in conjunction with a similar decline in the political impact of social class produced a vacuum in the basis of political orientations that has been occupied by core values. In the 1975 Referendum, for example, consistent with the government position, Labour supporters voted to stay in the European Economic Community despite strong opposition earlier in the campaign (Butler and Kitzinger 1976). There was less evidence of such strong party influence in the 2016 referendum, which saw the majority (64\%) of the pro-remain government's supporters voting to leave. Further research is necessary to help unravel the temporal and comparative conditions in which core values are more or less politically consequential and the extent to which parties shape the preferences of their constituencies. Also, of course, recent events on both sides of the Atlantic suggest it might be fruitful to delve further into the partisan impact of values other than those pertaining to redistribution and equality. 


\section{References}

Abramowitz, Alan I., and Kyle L. Saunders. 1998. 'Ideological Realignment in the U.S. Electorate.' Journal of Politics 60(3): 634-652.

Abramson, Paul. 1979. "Developing Party Identification: A Further Examination of LifeCycle, Generational, and Period Effects." American Journal of Political Science 23 (1): 78-96.

Adams, James, Jane Green, and Caitlin Milazzo. 2012. 'Has the British Public Depolarized along with Political Elites? An American Perspective on British Public Opinion.' Comparative Political Studies 45(4): 507-53.

Alwin, Duane F., and Jon A. Krosnick. 1991. "Aging, Cohorts and the Stability of Sociopolitical Orientations over the Life Span." American Journal of Sociology 97 (1): 169-195.

Andersen, Robert, James Tilley, and Anthony F. Heath. 2005.'Political knowledge and enlightened preferences: party choice through the electoral cycle'. British Journal of Political Science, 35(2): 285-302.

Anderson, Christopher J., Silvia Mendes, Yuliya Tverdova, and Haklin Kim. 2004. 'Endogenous economic voting: Evidence from the 1997 British Election.' Electoral Studies 23 (4): 683-708.

Ansolabehere, Stephen, Jonathan Rodden, and James M. Snyder, Jr. 2006. 'Purple America.' Journal of Economic Perspectives 20 (2): 97-118.

Ansolabehere, Stephen, Rodden, Jonathan, and James M. Snyder, Jr. 2008. 'The strength of issues: Using multiple measures to gauge preference stability, ideological constraint, and issue voting.' American Political Science Review 102(2): 215-232.

Baldassarri, Delia, and Gelman, Andrew. 2008. 'Partisans without constraint: Political polarization and trends in American public opinion.' American Journal of Sociology 114(2): 408-446.

Bara, Judith. 2006. The 2005 Manifestos: A Sense of Déja Vu? Journal of Elections, Public Opinion and Parties 16 (3):265 - 281.

Bara, Judith, and Ian Budge. 2001. Party Policy and Ideology: Still New Labour? Parliamentary Affairs 54:590 - 606.

Bartels, Larry. 2002. 'Beyond the running tally: partisan bias in political perceptions.' Political Behavior 24(2):117-150.

Bartels, Larry. 2008. Unequal Democracy: The Political Economy of the New Gilded Age. New York: Russell Sage Foundation, and Princeton, NJ: Princeton University Press.

Bartle, John. 1998. 'Left-right matters but does social class? Causal models for the 1992 general election.' British Journal of Political Science 28(2): 117-150.

Bartle, John. 2000. 'Political awareness, opinion constraint and the stability of ideological positions.' Political Studies 48: 467-484. 
Bartle, John. 2001. 'The measurement of party identification in Britain: Where do we stand now?' British Elections \& Parties Review, 11:1, 9-22.

Bartle, John. James Stimson and Sebastian Dellepiane-Avelleneda. 2011. 'The moving centre: Preferences for government activity in Britain, 1950-2005.' British Journal of Political Science, 41 (2): 259-285.

Bartle, John, James Stimson and Sebastian Dellepiane-Avelleneda. 2013. 'The dimensionality of British public preferences: a macro-level perspective.' Working Paper, University of Essex.

Budge, Ian. 1999. 'Party Policy and Ideology: Reversing the 1950s' in Geoffrey Evans and Pippa Norris eds., Critical Elections: British Parties and Voters in Long-term Perspective. London: Sage, 1-22.

Budge, Ian, Klingemann, Hans-Dieter, Volkens, Andrea, Bara, Judith, and Eric Tanenbaum. 2001. Mapping Policy Preferences: Estimates for Parties, Electors, and Governments 1945-1998. Oxford: Oxford University Press.

Butler, David and Uwe Kitzinger. 1976. The 1975 Referendum, London and Basingstoke: Macmillan.

Butler, David and Donald E. Stokes. 1974. Political change in Britain: The evolution of electoral choice. London: Macmillan.

Carsey, Thomas M. and Geoffrey Layman. 2006. 'Changing sides or changing minds? Party identification and policy preferences in the American electorate.' American Journal of Political Science 50(2): 464-477.

Chzhen Kat, Geoffrey Evans and Mark Pickup. 2014. 'When do economic perceptions matter for government approval? Examining the endogeneity of economic perceptions before and during the economic downturn' Political Behavior, 36: 291-313.

Curtice, John. 2016. 'Brexit: Behind the referendum'. Political Insight, September 2016, 4-7.

Dancy, Logan and Paul Goren. 2010. 'Party identification, issue attitudes, and the dynamics of political debate.' American Journal of Political Science 54(3): 686-699.

Erikson, Robert S., Michael B. Mackuen and James A. Stimson. 2002. The Macro Polity. Cambridge: Cambridge University Press.

Evans, Geoffrey and Robert Andersen. 2004. 'Do issues decide? Partisan conditioning and perceptions of party issue positions across the electoral cycle.' Journal of Elections, Public Opinion \& Parties 14 (1): 18-39.

Evans, Geoffrey and Robert Andersen. 2006. 'The political conditioning of economic perceptions.' Journal of Politics 68: 194-207.

Evans Geoffrey and Kat Chzhen. 2016. 'Re-evaluating Valence Models of Political Choice. Political Science: Research \& Methods, 4 (1): 199-220.

Evans, Geoffrey, Anthony Heath, and Mansur Lalljee. 1996. 'Measuring left-right and libertarian-authoritarian values in the British electorate.' British Journal of Sociology 47(1): 93-112. 
Evans, Geoffrey and Jonathan Mellon. 2016. 'Working class votes and Conservative losses: Solving the UKIP puzzle.' Parliamentary Affairs 69 (2): 464-79.

Evans, Geoffrey and Anand Menon. 2017. Brexit and British Politics. Cambridge: Polity Press.

Evans, Geoffrey and James Tilley. 2012. 'The depoliticization of inequality and redistribution: Explaining the decline of class voting.' Journal of Politics 74: 963-976.

Evans, Geoffrey and James Tilley. 2017. The New Politics of Class: The Political Exclusion of the British Working Class. Oxford: Oxford University Press.

Feldman Stanley. 1988. 'Structure and consistency in public opinion: the role of core beliefs and values.' American Journal of Political Science 32: 416-440.

Fiske, Susan T. and Shelley E. Taylor. 2013. Social Cognition 2nd ed., Thousand Oaks, CA: Sage.

Ford, Robert, and Matthew J. Goodwin. 2014. Revolt on the Right: Explaining Support for the Radical Right in Britain. Abingdon: Routledge.

Fuchs, Dieter and Hans-Dieter Klingemann. 1989. 'The Left-Right Schema,' in M. Kent Jennings and Jan W. van Deth (Eds.) Continuities in Political Action: A Longitudinal Study of Political Orientations in Three Western Democracies. Berlin: Walter de Gruyter.

Gelman, Andrew, and Gary King. 1993. 'Why are American presidential election polls so variable when votes are so predictable?' British Journal of Political Science, 23 (4), 409451.

Gilens, Martin. 2005. 'Inequality and Democratic Responsiveness.' Public Opinion Quarterly 69 (5): 778-96.

Goren, Paul. 2005. 'Party Identification and Core Political Values.' American Journal of Political Science 49 (3):881-96.

Green, Donald P. and Bradley Palmquist. 1990. 'Of Artifacts and Partisan Instability.' American Journal of Political Science 34(3): 872-902.

Green, Donald P. and Bradley Palmquist. 1994. 'How stable is party identification?' Political Behavior 16(4): 437-466.

Green, Donald P., Bradley Palmquist, and Eric Schickler. 2002. Partisan Hearts and Minds. New Haven: Yale University Press.

Green, Jane. 2007. 'When Voters and Parties Agree: Valence Issues and Party Competition.' Political Studies 55 (3): 629 - 655.

Green, Jane, and Sara B. Hobolt. 2008. 'Owning the Issue Agenda: Party Strategies and Vote Choices in British Elections'. Electoral Studies 27 (3): 460 - 476

Heath, Anthony, Evans, Geoffrey and Martin, Jean. 1994. 'The measurement of core beliefs and values: The development of balanced socialist/laissez faire and libertarian/authoritarian scales.' British Journal of Political Science 24(1): 115-132. 
Heath, Anthony, Roger Jowell and John Curtice. 1985. How Britain Votes. Oxford: Pergamon Press.

Heath, Anthony, Jowell, R. Curtice, J. 1985. How Britain Votes. Oxford: Pergamon Press.

Heath, Oliver. 2007. 'Explaining turnout decline in Britain, 1964-2005: Party identification and the political context'. Political Behavior 29 (4): 493-516.

Heath, Oliver. 2015. 'Policy representation, social representation and class voting in Britain'. British Journal of Political Science 45 (1): 173-93.

Heath, Oliver. 2016. 'Policy alienation, social alienation and working class abstention in Britain, 1964-2010'. British Journal of Political Science. http://dx. doi.org/10.1017/S0007123416000272.

Highton, Benjamin and Cindy D. Kam. 2011. 'The long-term dynamics of partisanship and issue orientation.' Journal of Politics 73(1): 202-215.

Inglehart, Ronald and Hans-Dieter Klingemann. 1976. 'Party Identification, Ideological Preference, and the Left-Right Dimension among Western Mass Publics,' in Ian Budge, Ivor Crewe and David Farlie (eds.), Party Identification and Beyond: Representations of Voting and Party Competition. London: Wiley.

Jenkins, Stephen P. 2011. Changing Fortunes: Income Mobility and Poverty Dynamics in Britain. Oxford: Oxford University Press.

Jennings, M. Kent. 1989. "The Crystallization of Orientations." In Continuities in Political Action, edited by Samuel H. Barnes, Jan W. van Deth, and M. Kent Jennings, 313-348. Berlin and New York: de Gruyter.

Klingemann, Hans-Dieter, Andrea Volkens, Judith Bara, Ian Budge, and Michael D. McDonald. 2006. Mapping Policy Preferences II: Estimates for Parties, Governments and Electors in the OECD, EU and Central and Eastern Europe 1990-2003. Oxford: Oxford University Press.

Ladner, Matthew and Christopher Wlezien. 2007. 'Partisan preferences, electoral prospects, and economic expectations.' Comparative Political Studies 40: 571-596.

Lau Richard R. and David P. Redlawsk. 2001. 'Advantages and Disadvantages of Cognitive Heuristics in Political Decision Making'. American Journal of Political Science, 45(4): 951-971.

Laver, Michael and Ian Budge. 1992. Party Policy and Government Coalitions. London: Macmillan.

Lazarsfeld, Paul F. 1959. 'Latent structure analysis.' In S. Koch (Ed.), Psychology: A Study of a Science, Vol. III. New York: McGraw-Hill.

McClosky, Herbert, and Zaller, John. 1984. The American Ethos: Public Attitudes toward Capitalism and Democracy. Cambridge, Mass.: Harvard University Press.

McCutcheon, Allan L. 1987. Latent Class Analysis. Newbury Park: Sage. 
Meltzer, Allan H. and Scott F. Richard. 1981. 'A rational theory of the size of government.' Journal of Political Economy 89(5):914-927.

Milazzo, Caitlin, James Adams, and Jane Green. 2012. 'Are Voter Decision Rules Endogenous to Parties' Policy Strategies? A Model with Applications to Elite Depolarization in PostThatcher Britain.' Journal of Politics 74(1): 262-276.

Neundorf, Anja and James Adams. 2016. 'The Micro-Foundations of Party Competition and Issue Ownership: The Reciprocal Effects of Citizens' Issue Salience and Party Attachments.'British Journal of Political Science (DOI:https://doi.org/10.1017/S0007123415000642)

Neundorf, Anja, Daniel Stegmueller, and Thomas J. Scotto. 2011. 'The individual level dynamics of bounded partisanship.' Public Opinion Quarterly 75(3): 458-482.

Rehm Philipp and Tim Reilly. 2010. 'United We Stand: Constituency Homogeneity and Comparative Party Polarization.' Electoral Studies 29(1): 40-53.

Rokeach, Milton. 1973. The Nature of Human Values. New York: Free Press.

Rose, David and Eric Harrison, eds. 2010. Social Class in Europe: An Introduction to the European Socio-Economic Classification. London: Routledge.

Sanders, David and Malcolm Brynin. 1999. 'The dynamics of party preference change in Britain, 1991-1996', Political Studies 47: 219-39.

Skrondal, Anders and Sophia Rabe-Hesketh. 2004. Generalized latent variable modeling: Multilevel, longitudinal, and structural equation models. Chapman \& Hall/CRC Press.

Sniderman, Paul, M. and Thomas Piazza. 1993. The Scar of Race. Cambridge MA: Harvard University Press.

Sniderman, Paul M. and Edward H. Stiglitz. 2012. The Reputational Premium. Princeton, NJ: Princeton University Press.

Webb, Paul. 2004. 'Party Responses to the Changing Electoral Markets in Britain.' In Political Parties and Electoral Change, ed. Peter Mair, Wolfgang Muller, and Fritz Plasser. London: Sage.

Wlezien, Christopher. 1995. 'The Public as Thermostat: Dynamics of Preferences for Spending', American Journal of Political Science, 39, 981-1000;

Wlezien, Christopher 2004. 'Patterns of Representation: Dynamics of Public Preferences and Policy', Journal of Politics, 66, 1-24.

Wlezien, Christopher and Stuart N. Soroka. 2005. 'Opinion-Policy Dynamics: Public Preferences and Public Expenditure in the United Kingdom', British Journal of Political Science, 35, 665-89.

Zaller, John. 1992. The Nature and Origins of Mass Opinion. Cambridge: Cambridge University Press.

Zaller, John and Stanley Feldman. 1992. 'A simple theory of the survey response.' American Journal of Political Science 36: 579-616. 


\section{Supplementary material}

\section{Core Political Values and the Long-Term Shaping of Partisanship in the British Electorate}

\section{Content}

A.1: Distinguishing between non-support and Liberal Democrat support........

A.2: Estimating effects using linear Structural Equation

Models.....

A.3: Supplementary information on the Latent Class

Analysis

a) Conditional probabilities of latent values on observed survey items

b) Classification statistics of latent variables

c) Conditional probabilities of latent values on observed survey items

A.4: Covariates on initial state.

A.5: Full results: Cross-lagged model by government period

a) Time period: 1991-1996 (polarization)

b) Time period: 1997-2007 (depolarization)

A.6: Full results: Cross-lagged model conditioned on age.

a) Dependent variable: Political values

b) Dependent variable: Partisanship

A.7: Full results: Cross-lagged model conditioned on education level......

a) Dependent variable: Political values

b) Dependent variable: Partisanship

A.8: Full results: Cross-lagged model conditioned on income quintiles

a) Dependent variable: Political values

b) Dependent variable: Partisanship 


\section{Appendix 1: Distinguishing between non-support and Liberal Democrat support}

In the main analysis the Liberal Democrats are included in a category with people who have no partisanship and those who support the smaller parties, such as the Greens. Support for all other smaller parties sums to a mere 1.5\%. If Liberal Democrats are treated as a separate category, party identification is distributed as shown in Table A1.1.

Table A1.1: Distribution of four-category partisanship (1991-2008)

\begin{tabular}{lrr}
\hline & Freq. & Percent \\
\hline No/other & 48,939 & 38.3 \\
PID & 31,272 & 24.5 \\
Cons & 36,762 & 28.8 \\
Labour & 10,676 & 8.4 \\
Lib-Dem & 127,649 & 100.0 \\
\hline Total & & \\
\hline
\end{tabular}

When using this four-category version of the party identification instead of only three categories, our conclusions do not change. Core values are more stable than partisanship and have a significant effect on party support, but not vice versa. Table A1.2 reports the cross-lagged and stability coefficient for a model that distinguishes supporters of the Liberal Democrats. Being a Lib-Dem supporter does not have a cross-lagged effect on a respondent's core political values. However, being left or right does affect whether someone identifies with the Lib-Dems. As generally expected, it is more likely that leftist respondents become Lib-Dem supporters $(b=0.20 ; p<0.01)$. Comparing the size of the effect to Labour and Conservative supporters it is however not surprising that the effect is much smaller for this more ideologically ambivalent and centrist party. For example, those with rightest values are more likely to become Conservative supporters in the next 
panel wave $(b=0.87 ; p<0.001)$ and less likely to support Labour $(b=0.66 ; p<0.001)$. The insignificant Wald-test confirms that party identification does not affect core values. 
Table A1.2: Cross-lagged interactions and stability coefficients (for four-category partisanship)

\begin{tabular}{|c|c|c|c|c|c|c|}
\hline & \multicolumn{2}{|c|}{ Rightist } & \multicolumn{2}{|c|}{ Centrist } & \multicolumn{2}{|c|}{ Leftist } \\
\hline & coef. & s.e. & coef. & s.e. & coef. & s.e. \\
\hline Intercept & $-0.87^{* *}$ & $\begin{array}{c}0.2 \\
7\end{array}$ & $1.64 * * *$ & $\begin{array}{c}0.2 \\
1\end{array}$ & $0.77^{-}$ & $\begin{array}{c}0.3 \\
7\end{array}$ \\
\hline
\end{tabular}

Cross-lagged
effects: Wald-test (df): $11.3(6)$

$\begin{array}{lcccccc}\text { Tories(t-1) } & -0.08 & 0.1 & 0.20 * * & 0.0 & - & 0.1 \\ & & 1 & & 7 & 0.12 & 0 \\ \text { No/oth PID(t-1) } & -0.20 * & 0.1 & 0.03 & 0.0 & 0.17 * & 0.0 \\ & & 0 & & 6 & & 8 \\ \text { Lib Dem(t-1) } & 0.19 & 0.1 & -0.16 & 0.0 & - & 0.1 \\ & & 5 & & 8 & 0.02 & 1 \\ \text { Labour(t-1) } & 0.10 & 0.1 & -0.07 & 0.0 & - & 0.0 \\ & & 2 & & 7 & 0.03 & 8\end{array}$

Stability coef. $\quad$ Wald-test (df): $2970.7(4)^{* * *}$

\begin{tabular}{lcccccc}
\hline Centrist (t-1) & $-0.92 * *$ & 0.2 & $1.26 * * *$ & 0.2 & - & 0.3 \\
& & 8 & & 2 & 0.35 & 9 \\
Leftist (t-1) & $-3.54^{* * *}$ & 0.4 & -0.35 & 0.2 & $3.88 * * *$ & 0.4 \\
& & 5 & & 8 & 2 \\
Rightist (t-1) & $4.45^{* * *}$ & 0.4 & $-0.92 *$ & 0.3 & $-{ }^{-* * *}$ & 0.7 \\
& & 2 & & 9 & 3.53 & 5
\end{tabular}

\begin{tabular}{|c|c|c|c|c|c|c|c|c|}
\hline & \multicolumn{2}{|c|}{ Tories } & \multicolumn{2}{|c|}{ No/oth PID } & \multicolumn{2}{|c|}{ Labour } & \multicolumn{2}{|l|}{ Lib dem } \\
\hline & coef. & s.e. & coef. & s.e. & coef. & s.e. & coef. & s.e. \\
\hline Intercept & $-0.45^{* * *}$ & $\begin{array}{c}0.0 \\
7\end{array}$ & $0.81^{* * *}$ & $\begin{array}{c}0.0 \\
4\end{array}$ & $0.21^{* * *}$ & $\begin{array}{c}0.0 \\
5\end{array}$ & $-0.57 * * *$ & 0.06 \\
\hline
\end{tabular}

\begin{tabular}{|c|c|c|c|c|c|c|c|c|}
\hline $\begin{array}{l}\text { Cross-lagged } \\
\text { effects: }\end{array}$ & Wald-test & (df): & $7(6)^{* *}$ & & & & & \\
\hline Centrist (t-1) & $-0.10 *$ & $\begin{array}{c}0.0 \\
5\end{array}$ & 0.02 & $\begin{array}{c}0.0 \\
3\end{array}$ & $0.11^{*}$ & $\begin{array}{c}0.0 \\
4\end{array}$ & -0.03 & 0.06 \\
\hline Leftist ( $t-1)$ & $-0.77^{* * *}$ & $\begin{array}{c}0.0 \\
8\end{array}$ & 0.02 & $\begin{array}{c}0.0 \\
5\end{array}$ & $0.55^{* * *}$ & $\begin{array}{c}0.0 \\
5\end{array}$ & $0.20 * *$ & 0.07 \\
\hline Rightist (t-1) & $0.87^{* * *}$ & $\begin{array}{c}0.0 \\
5\end{array}$ & -0.04 & $\begin{array}{c}0.0 \\
4\end{array}$ & $0.66^{-* * *}$ & $\begin{array}{c}0.0 \\
7\end{array}$ & $-0.17 *$ & 0.07 \\
\hline
\end{tabular}

Stability coef. Wald-test (df): $7761.6\left(9^{* * *}\right.$

\begin{tabular}{|c|c|c|c|c|c|c|c|c|}
\hline Tories(t-1) & $2.82 * * *$ & $\begin{array}{c}0.0 \\
8\end{array}$ & $-0.32^{* * *}$ & $\begin{array}{c}0.0 \\
6\end{array}$ & $1.68^{-* * *}$ & $\begin{array}{c}0.0 \\
9\end{array}$ & $-0.82 * * *$ & 0.10 \\
\hline No/oth PID(t-1) & $-0.20 *$ & $\begin{array}{c}0.0 \\
9\end{array}$ & $1.64 * * *$ & $\begin{array}{c}0.0 \\
6\end{array}$ & $0.56^{-* * *}$ & $\begin{array}{c}0.0 \\
7\end{array}$ & $-0.88 * * *$ & 0.10 \\
\hline $\operatorname{Lib} \operatorname{Dem}(t-1)$ & $-1.22 * * *$ & $\begin{array}{c}0.1 \\
4\end{array}$ & $-1.09 * * *$ & $\begin{array}{c}0.0 \\
9\end{array}$ & $0.58^{-* * *}$ & $\begin{array}{c}0.0 \\
8\end{array}$ & $2.89 * * *$ & 0.08 \\
\hline Labour(t-1) & $-1.41^{* * *}$ & $\begin{array}{c}0.1 \\
5\end{array}$ & $-0.24 * *$ & $\begin{array}{c}0.0 \\
8\end{array}$ & $2.83 * * *$ & $\begin{array}{c}0.0 \\
8\end{array}$ & $-1.19 * * *$ & 0.15 \\
\hline
\end{tabular}

Significance: ${ }^{*} \mathrm{p}<0.05 ;{ }^{* *} \mathrm{p}<0.01 ;{ }^{* * *} \mathrm{p}<0.001$. Data: BHPS 1991-2007. Effect coding.

Note: The model includes the effects of socio-demographic covariates on the initial partisanship and core values when respondents entered the panel. 


\section{Appendix 2: Estimating effects using linear Structural Equation Models}

To examine the robustness of the LCA findings to different measurement and estimation specifications we created a scale that measures party identification using a question on respondents' strength of partisanship. The variable is measured from 1 "Strong Labour" to 7 "Strong Tory". Such scales are typically used in US analyses. As with those studies, the variable constructed is normally distributed with the majority stating no partisanship and being classified as independent. However, unlike the American two-party system, the UK has several smaller parties that were set to missing values. Table A2.1 reports the distribution of the final ordinal measure of partisanship.

Table A2.1: Distribution of ordinal measure of partisanship (1991-2007)

\begin{tabular}{lrr}
\hline & Freq. & Percent \\
\hline Strong Labour & 3,072 & 2.7 \\
Weak Labour & 13,441 & 11.6 \\
Independent Labour & 19,661 & 17.0 \\
Independent & 48,939 & 42.2 \\
Independent Tory & 18,861 & 16.3 \\
Weak Tory & 10,033 & 8.7 \\
Strong Tory & 2,010 & 1.7 \\
\hline Total (N x T) & 116,017 & 100.0 \\
\hline
\end{tabular}

We then estimated the models shown in Table 2 using this ordinal measure of partisanship with two versions of our core value measures. First, we constructed an additive Likert scale of the core values items, which ranges from 6-30, with lower scores indicating left-wing values. Second, we estimate a latent, ordinal variable in a Structural Equation Model (SEM). Table A2.2 reports the results. 
Table A2.2 confirms the findings presented in the main manuscript. Lagged core values strongly predict subsequent partisanship $(\mathrm{b}=1.12, \mathrm{p}<0.001)$, but not vice versa. The cross-lagged effect of partisanship on core values is zero, no matter whether we model core values as observed or latent. We again find very strong stability coefficients with core values being significantly more stable than partisanship.

Table A2.2: Estimates using an ordinal measure of partisanship

\begin{tabular}{|c|c|c|c|c|}
\hline & \multicolumn{2}{|c|}{ DV: Core Values (Likert scale) } & \multicolumn{2}{|c|}{$\begin{array}{l}\text { DV: Ordinal } \\
\text { Partisanship }\end{array}$} \\
\hline & coef. & s.e. & coef. & s.e. \\
\hline Intercept & $1.76^{* * *}$ & 0.04 & $2.32 * * *$ & 0.05 \\
\hline Cross-lagged coef. & -0.31 & 0.18 & $1.21 * * *$ & 0.09 \\
\hline \multirow[t]{3}{*}{ Stability coef. } & $7.14^{* * *}$ & 0.20 & $6.26^{* * *}$ & 0.12 \\
\hline & \multicolumn{2}{|c|}{ DV: Core Values (latent scale) } & \multicolumn{2}{|c|}{$\begin{array}{l}\text { DV: Ordinal } \\
\text { Partisanship }\end{array}$} \\
\hline & coef. & S.e. & coef. & s.e. \\
\hline Intercept & $1.70 * * *$ & 0.07 & $1.71 * * *$ & 0.05 \\
\hline Cross-lagged coef. & -0.12 & 0.16 & $1.21 * * *$ & 0.09 \\
\hline Stability coef. & $6.96^{* * *}$ & 0.16 & $6.24 * * *$ & 0.12 \\
\hline Number of cases & \multicolumn{2}{|c|}{7,582} & & \\
\hline
\end{tabular}




\section{Appendix 3: Supplementary information on the Latent Class Analysis}

The aim of LCA is to classify respondents into 'true' groups that account for the observed scores on the response items, whether left or right, with the possibility of identifying a centrist latent class that bundles those that have no clear value positions. Imagine we have two items, 'ordinary people share nation's wealth' (A) and 'public services ought to be state owned' (B), which are proxies of what we are really interested in - 'true' political beliefs or values. The association between responses to these statements - i.e. disagreement with the former and agreement with the latter - is assumed to be caused by the same core value - being leftist. There is therefore no residual covariation between these two. Any observed relationship between (A) and (B) is simply because of a common 'underlying' unobserved trait - left-wing values.

Figure A3.1 plots the distribution of our three latent classes - leftist, centrist and rightist - on the six-item additive index score. The latent class model distinguishes extremely well between the three types of respondents. The ideologues, in particular, are very well separated, with only a small minority overlapping in the middle of the scale. As expected the centrist latent class also captures mid-range scores. Hardly any respondents in this classification are below 12 or above 20 on the $6-30$ scale. Based on this result, we feel confident that the classifications estimated using latent class modeling identify meaningful distinctions between different core political values. 


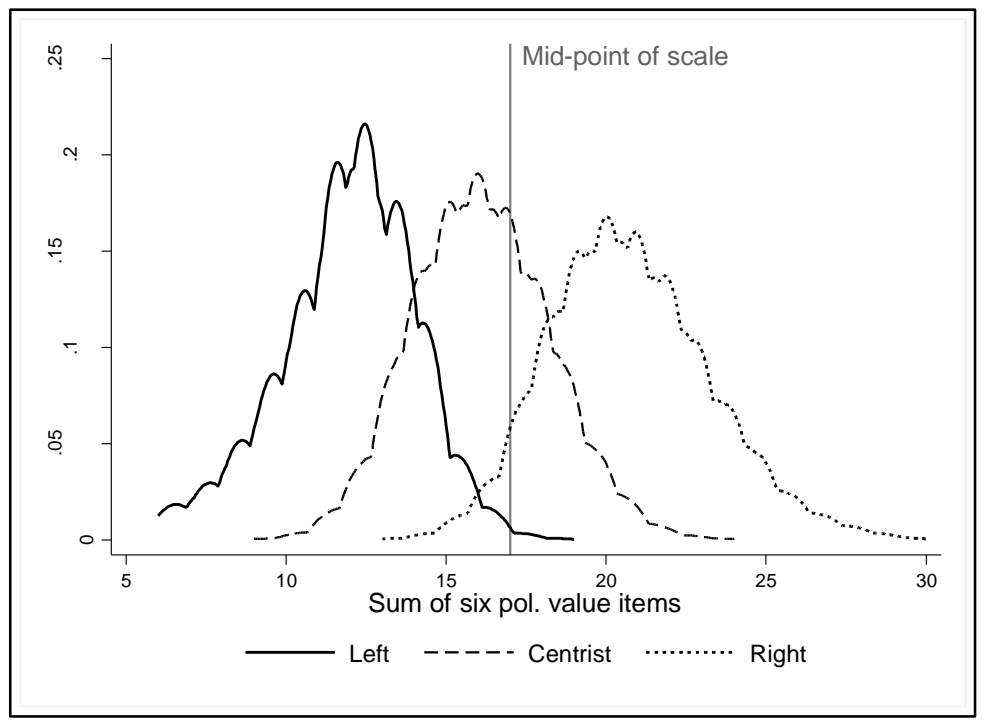

Figure A3.1: Distribution of latent classification of political values on an additive index of observed survey items

The classification statistics for the LCAs for both core values and partisanship are shown in Table A3.2. These indicate impressive goodness of fit for both analyses.

Table A3.2: Classification statistics of latent variables

\begin{tabular}{lcc}
\hline & Values & Partisanship \\
\cline { 2 - 3 } Classification errors & 0.077 & 0.056 \\
Reduction of errors & 0.816 & 0.901 \\
(Lambda) & 0.808 & 0.866 \\
Entropy R-squared & 0.805 & 0.874 \\
\hline
\end{tabular}

Finally, Table A3.3 presents latent probabilities for the six survey items on each of the latent classes. 
Table A3.3: Conditional probabilities of latent values on observed survey items

\begin{tabular}{|c|c|c|c|c|}
\hline \multicolumn{5}{|c|}{ Values: Classification } \\
\hline & Centrist & Leftist & Rightist & Overall \\
\hline Item A: 1 & 0.07 & 0.37 & 0.03 & 0.13 \\
\hline 2 & 0.53 & 0.57 & 0.37 & 0.50 \\
\hline 3 & 0.24 & 0.05 & 0.28 & 0.21 \\
\hline 4 & 0.15 & 0.01 & 0.30 & 0.15 \\
\hline 5 & 0.01 & 0.00 & 0.02 & 0.01 \\
\hline Mean & 2.48 & 1.70 & 2.90 & 2.41 \\
\hline Item B: 1 & 0.05 & 0.16 & 0.01 & 0.06 \\
\hline 2 & 0.34 & 0.51 & 0.10 & 0.32 \\
\hline 3 & 0.33 & 0.24 & 0.26 & 0.29 \\
\hline 4 & 0.26 & 0.09 & 0.52 & 0.28 \\
\hline 5 & 0.02 & 0.00 & 0.11 & 0.04 \\
\hline Mean & 2.87 & 2.28 & 3.63 & 2.92 \\
\hline Item C: 1 & 0.03 & 0.12 & 0.00 & 0.04 \\
\hline 2 & 0.29 & 0.51 & 0.05 & 0.28 \\
\hline 3 & 0.45 & 0.31 & 0.29 & 0.39 \\
\hline 4 & 0.22 & 0.06 & 0.54 & 0.26 \\
\hline 5 & 0.01 & 0.00 & 0.12 & 0.03 \\
\hline Mean & 2.90 & 2.30 & 3.73 & 2.96 \\
\hline Item D: 1 & 0.10 & 0.46 & 0.04 & 0.16 \\
\hline 2 & 0.56 & 0.50 & 0.37 & 0.51 \\
\hline 3 & 0.19 & 0.03 & 0.23 & 0.17 \\
\hline 4 & 0.14 & 0.01 & 0.32 & 0.15 \\
\hline 5 & 0.01 & 0.00 & 0.05 & 0.02 \\
\hline Mean & 2.39 & 1.59 & 2.97 & 2.36 \\
\hline Item E: 1 & 0.06 & 0.15 & 0.00 & 0.06 \\
\hline 2 & 0.40 & 0.57 & 0.09 & 0.37 \\
\hline 3 & 0.20 & 0.15 & 0.13 & 0.17 \\
\hline 4 & 0.31 & 0.13 & 0.62 & 0.34 \\
\hline 5 & 0.03 & 0.01 & 0.15 & 0.05 \\
\hline Mean & 2.85 & 2.28 & 3.83 & 2.95 \\
\hline Item F: 1 & 0.07 & 0.26 & 0.01 & 0.09 \\
\hline 2 & 0.48 & 0.61 & 0.14 & 0.44 \\
\hline 3 & 0.25 & 0.11 & 0.23 & 0.22 \\
\hline 4 & 0.18 & 0.03 & 0.48 & 0.21 \\
\hline 5 & 0.02 & 0.00 & 0.14 & 0.04 \\
\hline Mean & 2.60 & 1.90 & 3.61 & 2.68 \\
\hline
\end{tabular}




\section{Appendix 4: Covariates on initial state}

Table A4.1: Covariates on initial state

\begin{tabular}{|c|c|c|c|c|c|c|}
\hline & \multicolumn{2}{|c|}{$\begin{array}{c}\text { Conservatives- } \\
\text { PID }\end{array}$} & \multicolumn{2}{|c|}{ No/oth -PID } & \multicolumn{2}{|c|}{ Labour-PID } \\
\hline & coef. & s.e. & coef. & s.e. & coef. & s.e. \\
\hline Intercept & $-0.71^{* * *}$ & 0.10 & $1.24^{* * *}$ & 0.08 & $-0.53^{* * *}$ & 0.11 \\
\hline Age (entered panel) & $0.01^{* * *}$ & 0.00 & $-0.02 * * *$ & 0.00 & $0.00 *$ & 0.00 \\
\hline Male (48.3\%) & $-0.13^{* * *}$ & 0.03 & -0.03 & 0.02 & $0.16^{* * *}$ & 0.03 \\
\hline Female $(51.7 \%)$ & $0.13^{* * *}$ & 0.03 & 0.03 & 0.02 & $-0.16^{* * *}$ & 0.03 \\
\hline Social Class: Service (32\%) & -0.05 & 0.07 & 0.00 & 0.05 & 0.05 & 0.07 \\
\hline Intermediate (20\%) & $0.19^{* *}$ & 0.07 & $-0.15^{* *}$ & 0.05 & -0.04 & 0.07 \\
\hline Self-employed (10\%) & $0.24^{* *}$ & 0.09 & 0.14 & 0.08 & $-0.38^{* * *}$ & 0.11 \\
\hline Lower sales (15\%) & 0.02 & 0.07 & -0.03 & 0.06 & 0.01 & 0.08 \\
\hline Technicians (8\%) & -0.13 & 0.11 & -0.05 & 0.08 & $0.18^{*}$ & 0.09 \\
\hline Manual workers (15\%) & $-0.27^{* *}$ & 0.09 & 0.09 & 0.06 & $0.18^{*}$ & 0.07 \\
\hline Housing: Own (20\%) & 0.01 & 0.06 & 0.07 & 0.05 & -0.08 & 0.06 \\
\hline Mortgage (57\%) & $0.20^{* * *}$ & 0.04 & $-0.08 *$ & 0.03 & $-0.12^{* *}$ & 0.04 \\
\hline Social (15\%) & $-0.24 * * *$ & 0.06 & 0.03 & 0.05 & $0.22^{* * *}$ & 0.05 \\
\hline Rented (8\%) & 0.03 & 0.08 & -0.01 & 0.06 & -0.02 & 0.07 \\
\hline Education: primary (30\%) & 0.08 & 0.06 & $0.08 *$ & 0.04 & $-0.16^{* *}$ & 0.05 \\
\hline Low secondary-vocational (36\%) & $0.22 * * *$ & 0.05 & -0.01 & 0.04 & $-0.21 * * *$ & 0.05 \\
\hline High secondary -mid-vocational (9\%) & $0.30^{* * *}$ & 0.08 & $-0.26^{* * *}$ & 0.06 & -0.04 & 0.08 \\
\hline Higher vocational (16\%) & 0.05 & 0.06 & 0.02 & 0.05 & -0.07 & 0.06 \\
\hline \multirow[t]{3}{*}{ University Degree (9\%) } & $-0.65^{* * *}$ & 0.09 & $0.17^{* *}$ & 0.06 & $0.48^{* * *}$ & 0.08 \\
\hline & \multicolumn{2}{|c|}{ Right ideologue } & \multicolumn{2}{|c|}{ Centrist } & \multicolumn{2}{|c|}{ Left ideologue } \\
\hline & coef. & s.e. & coef. & s.e. & coef. & s.e. \\
\hline Intercept & $-1.50^{* * *}$ & 0.13 & $1.77^{* * *}$ & 0.08 & $-0.26^{*}$ & 0.11 \\
\hline Age (entered panel) & $0.01^{* * *}$ & 0.00 & $-0.02 * * *$ & 0.00 & $0.01^{* *}$ & 0.00 \\
\hline Male (48.3\%) & $0.26^{* * *}$ & 0.03 & $-0.10 * * *$ & 0.02 & $-0.16^{* * *}$ & 0.03 \\
\hline Female $(51.7 \%)$ & $-0.26^{* * *}$ & 0.03 & $0.10^{* * *}$ & 0.02 & $0.16^{* * *}$ & 0.03 \\
\hline Social Class: Service (32\%) & $0.36^{* * *}$ & 0.07 & $-0.18 * * *$ & 0.05 & $-0.18^{*}$ & 0.07 \\
\hline Intermediate (20\%) & 0.01 & 0.08 & 0.01 & 0.06 & -0.02 & 0.08 \\
\hline Self-employed (10\%) & $0.43^{* * *}$ & 0.10 & $-0.17 *$ & 0.08 & $-0.26 *$ & 0.11 \\
\hline Lower sales (15\%) & -0.05 & 0.10 & $0.17^{* *}$ & 0.06 & -0.12 & 0.09 \\
\hline Technicians (8\%) & $-0.51 * * *$ & 0.14 & $0.18^{*}$ & 0.09 & $0.32^{* *}$ & 0.11 \\
\hline Manual workers (15\%) & $-0.25 *$ & 0.11 & -0.01 & 0.07 & $0.26^{* *}$ & 0.09 \\
\hline Housing: Own (20\%) & $0.38^{* * *}$ & 0.07 & 0.01 & 0.05 & $-0.39 * * *$ & 0.06 \\
\hline Mortgage (57\%) & $0.25^{* * *}$ & 0.05 & -0.06 & 0.04 & $-0.20 * * *$ & 0.05 \\
\hline Social (15\%) & $-0.64^{* * *}$ & 0.10 & $0.18^{* *}$ & 0.06 & $0.46^{* * *}$ & 0.07 \\
\hline Rented (8\%) & 0.01 & 0.09 & $-0.13 *$ & 0.06 & 0.13 & 0.08 \\
\hline Education: primary (30\%) & $-0.58^{* * *}$ & 0.07 & $0.25^{* * *}$ & 0.04 & $0.32 * * *$ & 0.06 \\
\hline Low secondary-vocational (36\%) & $-0.22^{* * *}$ & 0.06 & $0.12^{* *}$ & 0.04 & 0.09 & 0.05 \\
\hline High secondary -mid-vocational (9\%) & 0.09 & 0.08 & -0.09 & 0.06 & 0.00 & 0.09 \\
\hline Higher vocational (16\%) & 0.12 & 0.07 & -0.01 & 0.05 & -0.10 & 0.07 \\
\hline
\end{tabular}


University Degree (9\%)

$0.58^{* * *} \quad 0.09$

$-0.27 * * * 0.07$

$-0.32 * * * 0.09$

Significance: ${ }^{*} \mathrm{p}<0.05 ;{ }^{* *} \mathrm{p}<0.01 ;{ }^{* * *} \mathrm{p}<0.001$. Data: BHPS 1991-2007. Note: Effect coding. 


\section{Appendix 5: Full results: Cross-lagged model by government period}

Table A5.a: Time period: 1991-1996 (polarization)

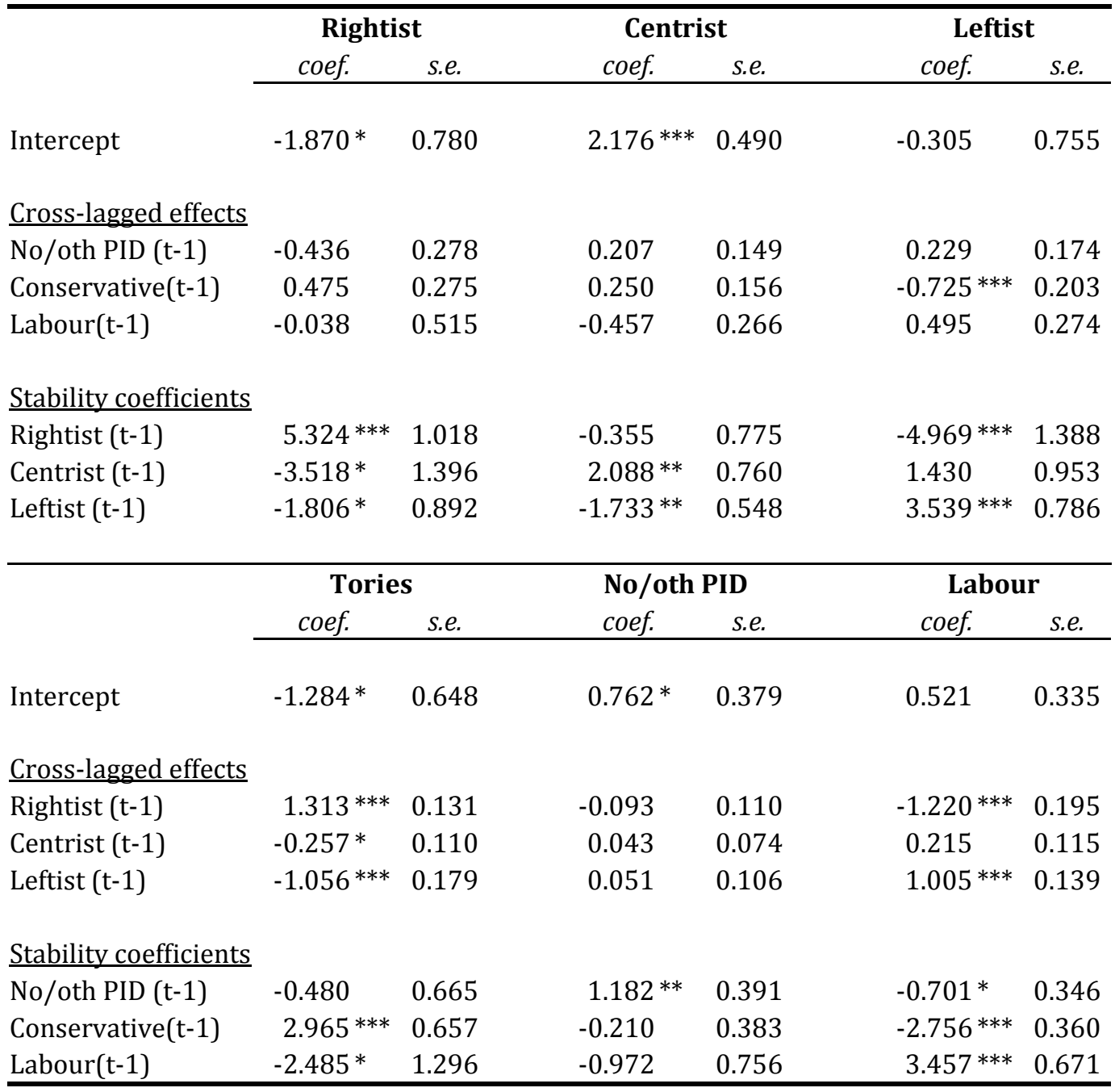

Significance: ${ }^{*} \mathrm{p}<0.05 ;{ }^{* *} \mathrm{p}<0.01 ;{ }^{* * *} \mathrm{p}<0.001$. Data: BHPS 1991-2007. Effect coding. 
Table A5.b: Time period: 1997-2007 (depolarization)

\begin{tabular}{|c|c|c|c|c|c|c|}
\hline & \multicolumn{2}{|c|}{ Rightist } & \multicolumn{2}{|c|}{ Centrist } & \multicolumn{2}{|c|}{ Leftist } \\
\hline & coef. & s.e. & coef. & s.e. & coef. & s.e. \\
\hline Intercept & $-1.026^{* * *}$ & 0.234 & $1.250 * * *$ & 0.148 & -0.224 & 0.181 \\
\hline \multicolumn{7}{|c|}{$\underline{\text { Cross-lagged effects }}$} \\
\hline No/oth PID (t-1) & -0.043 & 0.203 & -0.069 & 0.120 & 0.113 & 0.134 \\
\hline Labour(t-1) & 0.257 & 0.306 & -0.102 & 0.167 & -0.155 & 0.179 \\
\hline Conservative(t-1) & -0.213 & 0.230 & 0.171 & 0.144 & 0.042 & 0.179 \\
\hline \multicolumn{7}{|c|}{ Stability coefficients } \\
\hline Rightist (t-1) & $4.188 * * *$ & 0.360 & $-1.536^{* * *}$ & 0.256 & $-2.652 * * *$ & 0.369 \\
\hline Centrist (t-1) & $-1.603^{* * *}$ & 0.386 & $2.122 * * *$ & 0.224 & $-0.519 *$ & 0.257 \\
\hline \multirow[t]{3}{*}{ Leftist (t-1) } & $-2.585^{* * *}$ & 0.521 & $-0.586 *$ & 0.281 & $3.171^{* * *}$ & 0.313 \\
\hline & \multicolumn{2}{|c|}{ Tories } & \multicolumn{2}{|c|}{ No/oth PID } & \multicolumn{2}{|c|}{ Labour } \\
\hline & coef. & s.e. & coef. & s.e. & coef. & s.e. \\
\hline Intercept & -0.113 & 0.072 & $0.886^{* * *}$ & 0.064 & $-0.773^{* * *}$ & 0.102 \\
\hline \multicolumn{7}{|l|}{$\underline{\text { Cross-lagged effects }}$} \\
\hline Rightist (t-1) & $0.659 * * *$ & 0.075 & $-0.304 * * *$ & 0.064 & $-0.354 * * *$ & 0.099 \\
\hline Centrist (t-1) & -0.088 & 0.064 & 0.072 & 0.046 & 0.016 & 0.065 \\
\hline Leftist (t-1) & $-0.571^{* * *}$ & 0.094 & $0.232 * * *$ & 0.061 & $0.339 * * *$ & 0.075 \\
\hline \multicolumn{7}{|c|}{ Stability coefficients } \\
\hline No/oth PID (t-1) & $-0.527^{* * *}$ & 0.093 & $1.448^{* * *}$ & 0.091 & $-0.921 * * *$ & 0.146 \\
\hline Labour(t-1) & $-2.002 * * *$ & 0.110 & $-0.701^{* * *}$ & 0.082 & $2.703 * * *$ & 0.122 \\
\hline Conservative(t-1) & $2.528 * * *$ & 0.110 & $-0.747 * * *$ & 0.111 & $-1.782^{* * *}$ & 0.188 \\
\hline
\end{tabular}




\section{Appendix 6: Full results: Cross-lagged model conditioned on age}

Table A6.a: Dependent variable: Political values

\begin{tabular}{|c|c|c|c|c|c|c|c|}
\hline & \multirow{2}{*}{$\begin{array}{l}\text { Conditioned } \\
\text { Age }\end{array}$} & \multicolumn{2}{|c|}{ Rightist } & \multicolumn{2}{|c|}{ Centrist } & \multicolumn{2}{|c|}{ Leftist } \\
\hline & & coef. & s.e. & coef. & s.e. & coef. & s.e. \\
\hline \multicolumn{2}{|l|}{ Intercept } & $-0.93 * * *$ & 0.25 & $1.67^{* * *}$ & 0.20 & $-0.74 *$ & 0.36 \\
\hline \multicolumn{2}{|c|}{ Cross-lagged effects: } & \multicolumn{6}{|c|}{ Wald-test (df): 32.4 (24) } \\
\hline \multirow[t]{6}{*}{ Labour(t-1) } & $15-24$ & 0.29 & 0.24 & -0.21 & 0.13 & -0.08 & 0.17 \\
\hline & $25-34$ & 0.18 & 0.25 & -0.03 & 0.14 & -0.15 & 0.18 \\
\hline & $35-44$ & 0.74 & 0.43 & -0.38 & 0.23 & -0.36 & 0.24 \\
\hline & $45-55$ & -0.15 & 0.27 & -0.13 & 0.15 & 0.28 & 0.17 \\
\hline & $55-64$ & -0.25 & 0.30 & 0.10 & 0.16 & 0.15 & 0.19 \\
\hline & $65+$ & -0.15 & 0.35 & 0.05 & 0.19 & 0.10 & 0.22 \\
\hline \multirow[t]{6}{*}{ Tories(t-1) } & $15-24$ & -0.12 & 0.28 & 0.29 & 0.16 & -0.17 & 0.22 \\
\hline & $25-34$ & -0.15 & 0.24 & 0.12 & 0.16 & 0.03 & 0.24 \\
\hline & $35-44$ & $-0.62 *$ & 0.29 & $0.46^{* *}$ & 0.17 & 0.16 & 0.23 \\
\hline & $45-55$ & 0.27 & 0.21 & 0.13 & 0.14 & -0.39 & 0.20 \\
\hline & $55-64$ & 0.24 & 0.21 & -0.08 & 0.13 & -0.16 & 0.20 \\
\hline & $65+$ & 0.43 & 0.22 & -0.08 & 0.15 & -0.35 & 0.23 \\
\hline \multirow[t]{6}{*}{ No/oth PID(t-1) } & $15-24$ & -0.17 & 0.18 & -0.08 & 0.10 & 0.25 & 0.14 \\
\hline & $25-34$ & -0.03 & 0.18 & -0.09 & 0.11 & 0.12 & 0.15 \\
\hline & $35-44$ & -0.12 & 0.25 & -0.08 & 0.14 & 0.20 & 0.17 \\
\hline & $45-55$ & -0.12 & 0.21 & 0.01 & 0.12 & 0.11 & 0.16 \\
\hline & $55-64$ & 0.01 & 0.23 & -0.02 & 0.13 & 0.01 & 0.17 \\
\hline & $65+$ & -0.28 & 0.23 & 0.03 & 0.14 & 0.25 & 0.18 \\
\hline \multicolumn{2}{|l|}{ Stability coef. } & \multicolumn{6}{|c|}{ Wald-test (df): $2829.4(24)^{* * *}$} \\
\hline \multirow[t]{6}{*}{ Centrist (t-1) } & $15-24$ & $-0.86^{* *}$ & 0.33 & $1.30 * * *$ & 0.24 & -0.43 & 0.40 \\
\hline & $25-34$ & $-0.90 * *$ & 0.33 & $1.41^{* * *}$ & 0.24 & -0.51 & 0.39 \\
\hline & $35-44$ & $-1.42^{* *}$ & 0.50 & $1.66^{* * *}$ & 0.31 & -0.23 & 0.47 \\
\hline & $45-55$ & $-0.90 *$ & 0.36 & $1.19^{* * *}$ & 0.25 & -0.29 & 0.41 \\
\hline & $55-64$ & $-0.78 *$ & 0.37 & $0.98^{* * *}$ & 0.26 & -0.20 & 0.41 \\
\hline & $65+$ & $-0.95 *$ & 0.43 & $1.05^{* * *}$ & 0.29 & -0.10 & 0.46 \\
\hline \multirow[t]{6}{*}{ Rightist (t-1) } & $15-24$ & $4.57^{* * *}$ & 0.46 & $-1.22 * *$ & 0.40 & $-3.35^{* * *}$ & 0.74 \\
\hline & $25-34$ & $4.60 * * *$ & 0.45 & $-1.13^{* *}$ & 0.39 & $-3.46^{* * *}$ & 0.73 \\
\hline & $35-44$ & $4.76^{* * *}$ & 0.52 & $-1.09^{* *}$ & 0.42 & $-3.68^{* * *}$ & 0.78 \\
\hline & $45-55$ & $4.47^{* * *}$ & 0.44 & $-0.90 *$ & 0.39 & $-3.57^{* * *}$ & 0.73 \\
\hline & $55-64$ & $4.16^{* * *}$ & 0.44 & -0.58 & 0.38 & $-3.58 * * *$ & 0.73 \\
\hline & $65+$ & $3.98^{* * *}$ & 0.46 & -0.55 & 0.40 & $-3.42^{* * *}$ & 0.76 \\
\hline \multirow[t]{6}{*}{ Leftist (t-1) } & $15-24$ & $-3.71^{* * *}$ & 0.47 & -0.08 & 0.29 & $3.78^{* * *}$ & 0.43 \\
\hline & $25-34$ & $-3.69 * * *$ & 0.47 & -0.27 & 0.29 & $3.97^{* * *}$ & 0.43 \\
\hline & $35-44$ & $-3.34 * * *$ & 0.51 & -0.57 & 0.30 & $3.91^{* * *}$ & 0.44 \\
\hline & $45-55$ & $-3.57 * * *$ & 0.50 & -0.28 & 0.30 & $3.85^{* * *}$ & 0.43 \\
\hline & $55-64$ & $-3.38 * * *$ & 0.51 & -0.40 & 0.31 & $3.78 * * *$ & 0.44 \\
\hline & $65+$ & $-3.02 * * *$ & 0.53 & -0.50 & 0.31 & 3.52 *** & 0.45 \\
\hline
\end{tabular}

Table A6.b: Dependent variable: Partisanship 


\begin{tabular}{|c|c|c|c|c|c|c|c|}
\hline & \multirow{2}{*}{$\begin{array}{l}\text { Conditioned } \\
\text { Age }\end{array}$} & \multicolumn{2}{|c|}{ Tories } & \multicolumn{2}{|c|}{ No/oth PID } & \multicolumn{2}{|c|}{ Labour } \\
\hline & & coef. & s.e. & coef. & s.e. & coef. & s.e. \\
\hline \multicolumn{2}{|l|}{ Intercept } & $-0.66^{* * *}$ & 0.06 & $0.76^{* * *}$ & 0.04 & $-0.10 *$ & 0.05 \\
\hline \multicolumn{2}{|c|}{ Cross-lagged effects: } & \multicolumn{4}{|c|}{ Wald-test (df): $347.0(24)^{* * *}$} & & \\
\hline \multirow[t]{6}{*}{ Centrist (t-1) } & $15-24$ & -0.09 & 0.08 & 0.09 & 0.05 & 0.00 & 0.07 \\
\hline & $25-34$ & -0.09 & 0.08 & -0.02 & 0.05 & 0.10 & 0.07 \\
\hline & $35-44$ & 0.02 & 0.08 & -0.06 & 0.06 & 0.05 & 0.08 \\
\hline & $45-55$ & 0.12 & 0.12 & -0.12 & 0.08 & -0.01 & 0.10 \\
\hline & $55-64$ & $-0.24 *$ & 0.12 & -0.10 & 0.09 & 0.34 & 0.12 \\
\hline & $65+$ & $-0.38 *$ & 0.19 & -0.01 & 0.12 & $0.39 *$ & 0.17 \\
\hline \multirow[t]{6}{*}{ Rightist (t-1) } & $15-24$ & $0.68^{* * *}$ & 0.10 & $-0.19 *$ & 0.08 & $-0.49 * * *$ & 0.11 \\
\hline & $25-34$ & $0.83^{* * *}$ & 0.09 & -0.10 & 0.08 & $-0.73 * * *$ & 0.11 \\
\hline & $35-44$ & $0.73 * * *$ & 0.09 & -0.04 & 0.07 & $-0.69 * * *$ & 0.11 \\
\hline & $45-55$ & $0.81 * * *$ & 0.12 & $-0.25 * *$ & 0.09 & $-0.56^{* * *}$ & 0.14 \\
\hline & $55-64$ & $1.06^{* * *}$ & 0.13 & 0.04 & 0.12 & $-1.09 * * *$ & 0.19 \\
\hline & $65+$ & $0.85^{* * *}$ & 0.18 & 0.20 & 0.16 & $-1.04 * * *$ & 0.25 \\
\hline \multirow[t]{6}{*}{ Leftist (t-1) } & $15-24$ & $-0.59 * * *$ & 0.14 & 0.10 & 0.08 & $0.49^{* * *}$ & 0.10 \\
\hline & $25-34$ & $-0.74 * * *$ & 0.13 & 0.12 & 0.08 & $0.62 * * *$ & 0.10 \\
\hline & $35-44$ & $-0.74 * * *$ & 0.13 & 0.10 & 0.08 & $0.64 * * *$ & 0.10 \\
\hline & $45-55$ & $-0.93 * * *$ & 0.19 & $0.36^{* *}$ & 0.11 & $0.57 * * *$ & 0.13 \\
\hline & $55-64$ & $-0.81 * * *$ & 0.18 & 0.06 & 0.12 & $0.75^{* * *}$ & 0.16 \\
\hline & $65+$ & -0.47 & 0.28 & -0.19 & 0.17 & 0.65 ** & 0.21 \\
\hline \multicolumn{2}{|l|}{ Stability coef. } & \multicolumn{4}{|c|}{ Wald-test (df): $5122.4(24)^{* * *}$} & & \\
\hline \multirow[t]{6}{*}{ Labour(t-1) } & $15-24$ & $-1.65^{* * *}$ & 0.16 & $-0.46^{* * *}$ & 0.10 & $2.11^{* * *}$ & 0.10 \\
\hline & $25-34$ & $-1.54 * * *$ & 0.13 & $-0.81 * * *$ & 0.09 & $2.35^{* * *}$ & 0.09 \\
\hline & $35-44$ & $-1.94 * * *$ & 0.17 & $-0.72 * * *$ & 0.11 & $2.67 * * *$ & 0.12 \\
\hline & $45-55$ & $-2.05^{* * *}$ & 0.24 & $-0.71^{* * *}$ & 0.14 & $2.77^{* * *}$ & 0.16 \\
\hline & $55-64$ & $-2.35^{* * *}$ & 0.24 & $-0.46^{* * *}$ & 0.14 & $2.80 * * *$ & 0.16 \\
\hline & $65+$ & $-2.51^{* * *}$ & 0.30 & $-0.62 * * *$ & 0.18 & $3.13^{* * *}$ & 0.23 \\
\hline \multirow[t]{6}{*}{ Tories(t-1) } & $15-24$ & $2.18^{* * *}$ & 0.10 & $-0.60 * * *$ & 0.08 & $-1.57 * * *$ & 0.10 \\
\hline & $25-34$ & $2.26^{* * *}$ & 0.09 & $-0.52 * * *$ & 0.08 & $-1.73 * * *$ & 0.11 \\
\hline & $35-44$ & $2.53^{* * *}$ & 0.11 & $-0.57^{* * *}$ & 0.09 & $-1.96^{* * *}$ & 0.12 \\
\hline & $45-55$ & $2.70 * * *$ & 0.14 & $-0.55^{* * *}$ & 0.11 & $-2.15^{* * *}$ & 0.16 \\
\hline & $55-64$ & $2.69 * * *$ & 0.14 & $-0.77^{* * *}$ & 0.12 & $-1.92 * * *$ & 0.18 \\
\hline & $65+$ & $3.21 * * *$ & 0.20 & $-0.68^{* * *}$ & 0.17 & $-2.53 * * *$ & 0.27 \\
\hline \multirow[t]{6}{*}{ No/oth PID(t-1) } & $15-24$ & $-0.53 * * *$ & 0.11 & $1.06^{* * *}$ & 0.07 & $-0.53 * * *$ & 0.08 \\
\hline & $25-34$ & $-0.71 * * *$ & 0.10 & $1.33^{* * *}$ & 0.07 & $-0.62 * * *$ & 0.09 \\
\hline & $35-44$ & $-0.59 * * *$ & 0.12 & $1.30 * * *$ & 0.08 & $-0.71 * * *$ & 0.10 \\
\hline & $45-55$ & $-0.65^{* * *}$ & 0.17 & $1.26^{* * *}$ & 0.11 & $-0.62 * * *$ & 0.13 \\
\hline & $55-64$ & -0.34 & 0.18 & $1.23^{* * *}$ & 0.11 & $-0.88^{* * *}$ & 0.16 \\
\hline & $65+$ & $-0.70 * *$ & 0.24 & $1.30^{* * *}$ & 0.15 & $-0.60 * *$ & 0.21 \\
\hline
\end{tabular}

Significance: ${ }^{*} \mathrm{p}<0.05 ;{ }^{* *} \mathrm{p}<0.01{ }^{* * *} \mathrm{p}<0.001$. Data: BHPS 1991-2007. Effect coding.

Note: The model includes the effects of socio-demographic covariates on the initial partisanship and core values when respondents entered the panel. 


\section{Appendix 7: Full results: Cross-lagged model conditioned on education level}

Table A7.a: Dependent variable: Political values

\begin{tabular}{|c|c|c|c|c|c|c|c|}
\hline & \multirow{3}{*}{$\begin{array}{l}\text { Conditioned } \\
\text { Education }\end{array}$} & \multicolumn{2}{|c|}{ Rightist } & \multicolumn{2}{|c|}{ Centrist } & \multicolumn{2}{|c|}{ Leftist } \\
\hline & & coef. & s.e. & coef. & s.e. & coef. & s.e. \\
\hline & & & & & & & \\
\hline \multicolumn{2}{|l|}{ Intercept } & $-1.05^{* * *}$ & 0.15 & $1.70^{* * *}$ & 0.10 & $-0.65^{* * *}$ & 0.16 \\
\hline \multicolumn{2}{|c|}{ Cross-lagged effects: } & \multicolumn{4}{|c|}{ Wald-test (df): 25.3 (24) } & & \\
\hline \multirow[t]{6}{*}{ No/oth PID(t-1) } & No qualif & -0.11 & 0.17 & -0.04 & 0.10 & 0.15 & 0.12 \\
\hline & Less than 0-levels & -0.33 & 0.27 & 0.07 & 0.15 & 0.26 & 0.19 \\
\hline & O-levels & -0.26 & 0.23 & -0.15 & 0.14 & $0.41 *$ & 0.18 \\
\hline & A-levels & -0.24 & 0.20 & -0.06 & 0.14 & 0.30 & 0.22 \\
\hline & Oth degree & -0.02 & 0.17 & -0.02 & 0.10 & 0.04 & 0.14 \\
\hline & Uni degree & -0.16 & 0.27 & -0.30 & 0.27 & 0.47 & 0.47 \\
\hline \multirow[t]{6}{*}{ Labour(t-1) } & No qualif & -0.19 & 0.26 & -0.06 & 0.14 & 0.24 & 0.15 \\
\hline & Less than 0-levels & 0.05 & 0.39 & -0.14 & 0.21 & 0.09 & 0.23 \\
\hline & O-levels & 0.17 & 0.35 & -0.12 & 0.19 & -0.05 & 0.22 \\
\hline & A-levels & 0.18 & 0.30 & -0.05 & 0.18 & -0.13 & 0.27 \\
\hline & Oth degree & 0.28 & 0.25 & -0.04 & 0.14 & -0.24 & 0.17 \\
\hline & Uni degree & -0.18 & 0.31 & -0.23 & 0.26 & 0.41 & 0.50 \\
\hline \multirow[t]{6}{*}{ Tories(t-1) } & No qualif & 0.30 & 0.18 & 0.10 & 0.11 & $-0.39 * *$ & 0.15 \\
\hline & Less than 0-levels & 0.28 & 0.28 & 0.07 & 0.17 & -0.34 & 0.24 \\
\hline & O-levels & 0.09 & 0.26 & 0.28 & 0.17 & -0.37 & 0.25 \\
\hline & A-levels & 0.06 & 0.26 & 0.11 & 0.20 & -0.17 & 0.34 \\
\hline & Oth degree & -0.26 & 0.21 & 0.06 & 0.13 & 0.20 & 0.19 \\
\hline & Uni degree & 0.34 & 0.51 & 0.53 & 0.51 & -0.87 & 0.93 \\
\hline \multicolumn{2}{|l|}{$\underline{\text { Stability coef. }}$} & \multicolumn{4}{|c|}{ Wald-test (df): $2856.2(24)^{* * *}$} & & \\
\hline \multirow[t]{6}{*}{ Leftist $(\mathrm{t}-1)$} & No qualif & $-2.83 * * *$ & 0.36 & $-0.55^{* *}$ & 0.19 & $3.38^{* * *}$ & 0.24 \\
\hline & Less than O-levels & $-2.61 * * *$ & 0.46 & $-0.62 *$ & 0.25 & $3.23^{* * *}$ & 0.29 \\
\hline & O-levels & $-2.97 * * *$ & 0.45 & $-0.57^{*}$ & 0.24 & $3.54^{* * *}$ & 0.30 \\
\hline & A-levels & $-3.85^{* * *}$ & 0.39 & -0.14 & 0.23 & $3.99^{* * *}$ & 0.32 \\
\hline & Oth degree & $-3.91 * * *$ & 0.37 & -0.26 & 0.20 & $4.17^{* * *}$ & 0.26 \\
\hline & Uni degree & $-5.15^{* * *}$ & 0.42 & $0.84^{* *}$ & 0.32 & $4.30^{* * *}$ & 0.48 \\
\hline \multirow[t]{6}{*}{ Centrist (t-1) } & No qualif & $-1.26^{* * *}$ & 0.30 & $1.11^{* * *}$ & 0.17 & 0.15 & 0.22 \\
\hline & Less than 0-levels & $-1.28^{* *}$ & 0.42 & $1.28^{* * *}$ & 0.24 & 0.00 & 0.30 \\
\hline & O-levels & $-1.26^{* *}$ & 0.40 & $1.63^{* * *}$ & 0.23 & -0.38 & 0.31 \\
\hline & A-levels & -0.24 & 0.29 & $1.32^{* * *}$ & 0.20 & $-1.09 * * *$ & 0.33 \\
\hline & Oth degree & $-0.80 * *$ & 0.28 & $1.39 * * *$ & 0.17 & $-0.59 *$ & 0.24 \\
\hline & Uni degree & 0.44 & 0.32 & $1.26^{* * *}$ & 0.29 & $-1.71^{* * *}$ & 0.51 \\
\hline \multirow[t]{6}{*}{ Rightist (t-1) } & No qualif & $4.10^{* * *}$ & 0.27 & $-0.56^{* *}$ & 0.19 & $-3.53 * * *$ & 0.34 \\
\hline & Less than 0-levels & $3.89 * * *$ & 0.35 & $-0.67^{* *}$ & 0.23 & $-3.22 * * *$ & 0.40 \\
\hline & O-levels & $4.23 * * *$ & 0.34 & $-1.06^{* * *}$ & 0.24 & $-3.16^{* * *}$ & 0.42 \\
\hline & A-levels & $4.09 * * *$ & 0.32 & $-1.19 * * *$ & 0.24 & $-2.90 * * *$ & 0.43 \\
\hline & Oth degree & $4.71^{* * *}$ & 0.28 & $-1.13^{* * *}$ & 0.20 & $-3.59 * * *$ & 0.34 \\
\hline & Degree & $4.71 * * *$ & 0.49 & $-2.11^{* * *}$ & 0.51 & $-2.60 * *$ & 0.88 \\
\hline
\end{tabular}


Table A7.b: Dependent variable: Partisanship

\begin{tabular}{|c|c|c|c|c|c|c|c|}
\hline & & \multicolumn{2}{|c|}{ Tories } & \multicolumn{2}{|c|}{ No/oth PID } & \multicolumn{2}{|c|}{ Labour } \\
\hline & & coef. & s.e. & coef. & s.e. & coef. & s.e. \\
\hline \multicolumn{2}{|l|}{ Intercept } & $-0.55^{* * *}$ & 0.05 & $0.73^{* * *}$ & 0.04 & $-0.18^{* * *}$ & 0.04 \\
\hline \multicolumn{2}{|c|}{ Cross-lagged effects: } & \multicolumn{4}{|c|}{ Wald-test (df): $386.6(24)^{* * *}$} & & \\
\hline \multirow[t]{6}{*}{ Leftist $(\mathrm{t}-1)$} & No qualif & $-0.62 * * *$ & 0.13 & 0.04 & 0.09 & $0.58^{* * *}$ & 0.11 \\
\hline & Less than 0-levels & $-0.83 * * *$ & 0.19 & 0.02 & 0.13 & $0.81^{* * *}$ & 0.15 \\
\hline & O-levels & $-0.92 * * *$ & 0.15 & $0.24 *$ & 0.10 & $0.68^{* * *}$ & 0.11 \\
\hline & A-levels & $-0.99 * * *$ & 0.23 & 0.23 & 0.15 & $0.76^{* * *}$ & 0.17 \\
\hline & Oth degree & $-0.55^{* * *}$ & 0.12 & 0.11 & 0.08 & $0.43^{* * *}$ & 0.09 \\
\hline & Uni degree & $-0.66^{* * *}$ & 0.20 & -0.01 & 0.13 & $0.67^{* * *}$ & 0.14 \\
\hline \multirow[t]{6}{*}{ Centrist (t-1) } & No qualif & $-0.19 *$ & 0.09 & -0.07 & 0.07 & $0.27^{* *}$ & 0.10 \\
\hline & Less than 0 -levels & -0.11 & 0.12 & -0.01 & 0.09 & 0.12 & 0.11 \\
\hline & O-levels & -0.03 & 0.09 & -0.01 & 0.06 & 0.04 & 0.08 \\
\hline & A-levels & 0.02 & 0.13 & -0.15 & 0.09 & 0.13 & 0.11 \\
\hline & Oth degree & -0.13 & 0.08 & 0.09 & 0.05 & 0.04 & 0.07 \\
\hline & Uni degree & $-0.25 *$ & 0.13 & 0.03 & 0.08 & $0.23 *$ & 0.11 \\
\hline \multirow[t]{6}{*}{ Rightist (t-1) } & No qualif & $0.82 * * *$ & 0.12 & 0.03 & 0.10 & $-0.85^{* * *}$ & 0.16 \\
\hline & Less than O-levels & $0.94^{* * *}$ & 0.16 & -0.01 & 0.14 & $-0.93^{* * *}$ & 0.19 \\
\hline & O-levels & $0.95^{* * *}$ & 0.11 & $-0.23^{* *}$ & 0.09 & $-0.71^{* * *}$ & 0.13 \\
\hline & A-levels & $0.97^{* * *}$ & 0.16 & -0.08 & 0.13 & $-0.89 * * *$ & 0.19 \\
\hline & Oth degree & $0.68^{* * *}$ & 0.08 & $-0.20 * *$ & 0.06 & $-0.48^{* * *}$ & 0.09 \\
\hline & Uni degree & $0.92 * * *$ & 0.13 & -0.02 & 0.10 & $-0.90 * * *$ & 0.14 \\
\hline \multicolumn{2}{|l|}{ Stability coef. } & \multicolumn{4}{|c|}{ Wald-test (df): $5428.9(24)^{* * *}$} & & \\
\hline \multirow[t]{6}{*}{ No/oth PID(t-1) } & No qualif & $-0.82 * * *$ & 0.14 & $1.33^{* * *}$ & 0.09 & $-0.51^{* * *}$ & 0.12 \\
\hline & Less than O-levels & $-0.68^{* * *}$ & 0.17 & $1.35^{* * *}$ & 0.11 & $-0.67^{* * *}$ & 0.14 \\
\hline & O-levels & $-0.82 * * *$ & 0.12 & $1.29 * * *$ & 0.08 & $-0.47^{* * *}$ & 0.10 \\
\hline & A-levels & $-0.56^{* * *}$ & 0.15 & $1.27^{* * *}$ & 0.10 & $-0.71^{* * *}$ & 0.13 \\
\hline & Oth degree & $-0.58 * * *$ & 0.10 & $1.28^{* * *}$ & 0.07 & $-0.70^{* * *}$ & 0.09 \\
\hline & Uni degree & $-0.79 * * *$ & 0.14 & $1.37^{* * *}$ & 0.09 & $-0.58 * * *$ & 0.13 \\
\hline \multirow[t]{6}{*}{ Labour(t-1) } & No qualif & $-1.94 * * *$ & 0.17 & $-0.70 * * *$ & 0.10 & $2.64^{* * *}$ & 0.12 \\
\hline & Less than O-levels & $-1.61^{* * *}$ & 0.20 & $-0.62^{* * *}$ & 0.13 & $2.22^{* * *}$ & 0.14 \\
\hline & O-levels & $-1.52 * * *$ & 0.15 & $-0.83 * * *$ & 0.10 & $2.35^{* * *}$ & 0.11 \\
\hline & A-levels & $-1.69 * * *$ & 0.22 & $-0.83 * * *$ & 0.15 & $2.52 * * *$ & 0.15 \\
\hline & Oth degree & $-1.85^{* * *}$ & 0.15 & $-0.66^{* * *}$ & 0.09 & $2.51^{* * *}$ & 0.10 \\
\hline & Uni degree & $-1.66^{* * *}$ & 0.18 & $-0.95^{* * *}$ & 0.13 & $2.61^{* * *}$ & 0.13 \\
\hline \multirow[t]{6}{*}{ Tories(t-1) } & No qualif & $2.76^{* * *}$ & 0.11 & $-0.63^{* * *}$ & 0.10 & $-2.13^{* * *}$ & 0.16 \\
\hline & Less than O-levels & $2.29 * * *$ & 0.13 & $-0.73^{* * *}$ & 0.13 & $-1.56^{* * *}$ & 0.17 \\
\hline & O-levels & $2.34^{* * *}$ & 0.10 & $-0.46^{* * *}$ & 0.09 & $-1.88^{* * *}$ & 0.13 \\
\hline & A-levels & $2.25 * * *$ & 0.14 & $-0.44^{* * *}$ & 0.12 & $-1.81^{* * *}$ & 0.17 \\
\hline & Oth degree & $2.44^{* * *}$ & 0.09 & $-0.62^{* * *}$ & 0.08 & $-1.82^{* * *}$ & 0.11 \\
\hline & Degree & $2.45^{* * *}$ & 0.14 & $-0.43^{* * *}$ & 0.11 & $-2.03^{* * *}$ & 0.16 \\
\hline
\end{tabular}

Significance: ${ }^{*} \mathrm{p}<0.05 ;{ }^{* *} \mathrm{p}<0.01{ }^{* * *} \mathrm{p}<0.001$. Data: BHPS 1991-2007. Effect coding.

Note: The model includes the effects of age, social class, gender, education, and housing on the initial partisanship and core values when respondents entered the panel. 


\section{Appendix 8: Full results: Cross-lagged model conditioned on income quintiles}

Table A8.a: Dependent variable: Political values

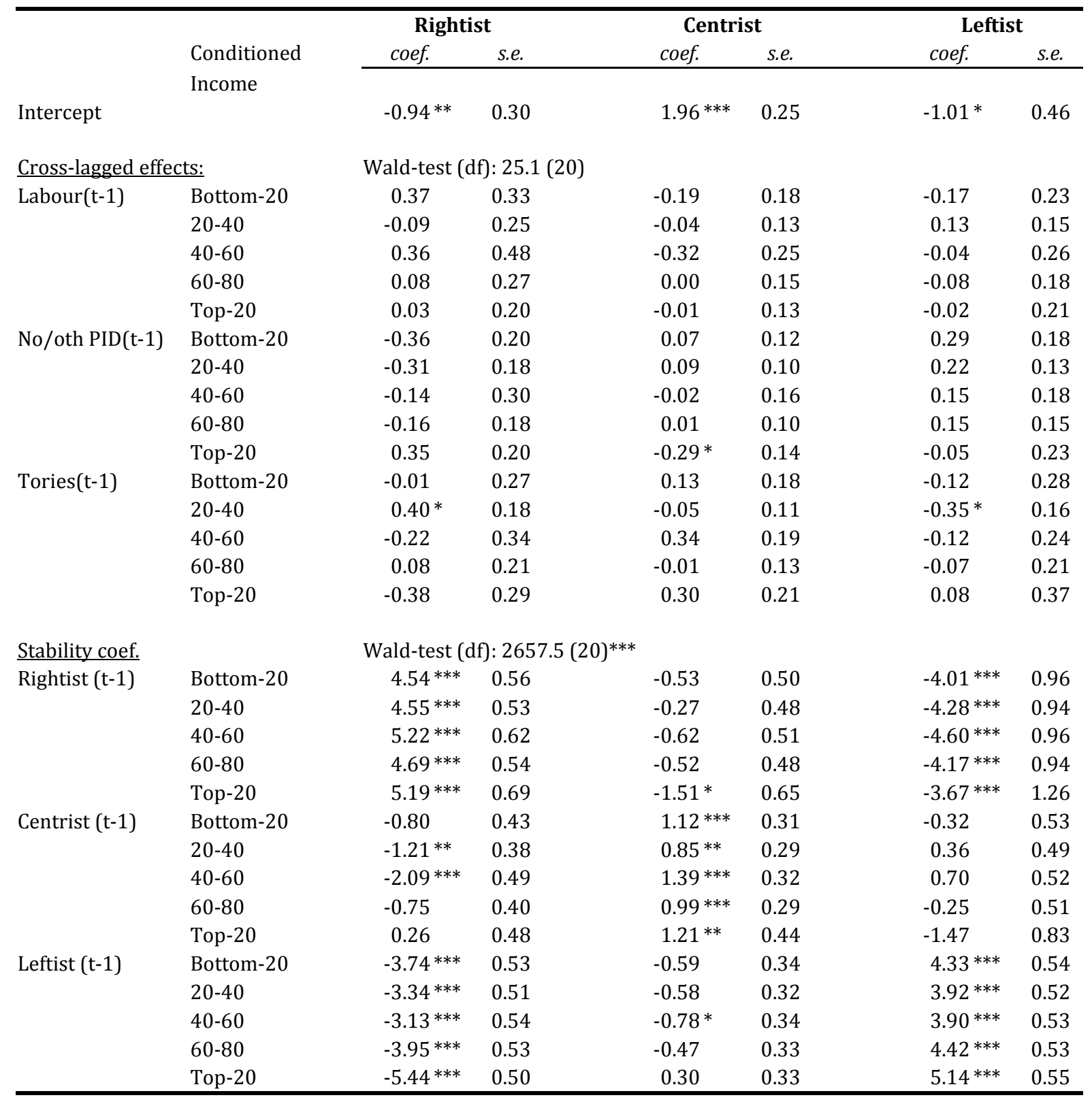


Table A8.b: Dependent variable: Partisanship

\begin{tabular}{|c|c|c|c|c|c|c|c|}
\hline & & Torie & & No/oth & PID & Labou & \\
\hline & & coef. & s.e. & coef. & s.e. & coef. & s.e. \\
\hline Intercept & & $-0.57^{* * *}$ & 0.05 & $0.71^{* * *}$ & 0.04 & $-0.15^{* *}$ & 0.04 \\
\hline Cross-lagged effe & & Wald-test & $(d f): 38$ & & & & \\
\hline Rightist (t-1) & Bottom-20 & $0.98 * * *$ & 0.14 & $-0.37 * * *$ & 0.11 & $-0.61^{* * *}$ & 0.16 \\
\hline & $20-40$ & $0.77^{* * *}$ & 0.12 & -0.08 & 0.11 & $-0.69 * * *$ & 0.16 \\
\hline & $40-60$ & $0.99 * * *$ & 0.12 & 0.00 & 0.10 & $-0.99 * * *$ & 0.15 \\
\hline & $60-80$ & $0.80 * * *$ & 0.09 & -0.02 & 0.08 & $-0.78 * * *$ & 0.12 \\
\hline & Top-20 & $0.75^{* * *}$ & 0.09 & $-0.16^{*}$ & 0.07 & $-0.58 * * *$ & 0.10 \\
\hline Centrist (t-1) & Bottom-20 & 0.01 & 0.10 & -0.03 & 0.07 & 0.02 & 0.09 \\
\hline & $20-40$ & -0.16 & 0.10 & 0.05 & 0.07 & 0.11 & 0.10 \\
\hline & $40-60$ & $-0.29 * * *$ & 0.10 & 0.09 & 0.07 & $0.20 *$ & 0.09 \\
\hline & $60-80$ & -0.07 & 0.08 & -0.08 & 0.06 & $0.15^{*}$ & 0.08 \\
\hline & Top-20 & -0.09 & 0.09 & 0.02 & 0.06 & 0.07 & 0.08 \\
\hline Leftist $(\mathrm{t}-1)$ & Bottom-20 & $-0.99 * * *$ & 0.18 & $0.40^{* * *}$ & 0.11 & $0.59 * * *$ & 0.13 \\
\hline & $20-40$ & $-0.61^{* * *}$ & 0.15 & 0.03 & 0.10 & $0.58^{* * *}$ & 0.12 \\
\hline & $40-60$ & $-0.70 * * *$ & 0.15 & -0.09 & 0.10 & $0.79^{* * *}$ & 0.12 \\
\hline & $60-80$ & $-0.73 * * *$ & 0.12 & 0.11 & 0.08 & $0.63^{* * *}$ & 0.10 \\
\hline & Top-20 & $-0.66^{* * *}$ & 0.15 & 0.15 & 0.10 & $0.51^{* * *}$ & 0.11 \\
\hline Stability coef. & & Wald-test & (df): 5 & $* * *$ & & & \\
\hline Labour(t-1) & Bottom-20 & $-1.59 * * *$ & 0.18 & $-0.71^{* * *}$ & 0.12 & $2.30^{* * *}$ & 0.12 \\
\hline & $20-40$ & $-1.77^{* * *}$ & 0.16 & $-0.68^{* * *}$ & 0.11 & $2.44^{* * *}$ & 0.11 \\
\hline & $40-60$ & $-2.07 * * *$ & 0.18 & $-0.49 * * *$ & 0.11 & $2.56^{* * *}$ & 0.12 \\
\hline & $60-80$ & $-1.64 * * *$ & 0.15 & $-0.77 * * *$ & 0.10 & $2.41^{* * *}$ & 0.10 \\
\hline No/oth PID(t-1) & Top-20 & $-1.78 * * *$ & 0.15 & $-0.91 * * *$ & 0.10 & $2.69 * * *$ & 0.11 \\
\hline & Bottom-20 & $-0.80 * * *$ & 0.13 & $1.27^{* * *}$ & 0.09 & $-0.46^{* * *}$ & 0.11 \\
\hline & $20-40$ & $-0.84 * * *$ & 0.14 & $1.40^{* * *}$ & 0.09 & $-0.56^{* * *}$ & 0.11 \\
\hline & $40-60$ & $-0.54 * * *$ & 0.12 & $1.28 * * *$ & 0.08 & $-0.75^{* * *}$ & 0.11 \\
\hline & $60-80$ & $-0.66^{* * *}$ & 0.11 & $1.33^{* * *}$ & 0.08 & $-0.67^{* * *}$ & 0.09 \\
\hline Tories(t-1) & Top-20 & $-0.65 * * *$ & 0.11 & $1.33^{* * *}$ & 0.08 & $-0.69 * * *$ & 0.10 \\
\hline & Bottom-20 & $2.39 * * *$ & 0.12 & $-0.56^{* * *}$ & 0.10 & $-1.83 * * *$ & 0.15 \\
\hline & $20-40$ & $2.61 * * *$ & 0.11 & $-0.73 * * *$ & 0.10 & $-1.88 * * *$ & 0.15 \\
\hline & $40-60$ & $2.61 * * *$ & 0.11 & $-0.80 * * *$ & 0.10 & $-1.81^{* * *}$ & 0.13 \\
\hline & $60-80$ & $2.30 * * *$ & 0.09 & $-0.55^{* * *}$ & 0.08 & $-1.74 * * *$ & 0.11 \\
\hline & Top-20 & $2.42^{* * *}$ & 0.10 & $-0.42^{* * *}$ & 0.09 & $-2.00^{* * *}$ & 0.13 \\
\hline
\end{tabular}

Significance: ${ }^{*} \mathrm{p}<0.05 ;{ }^{* *} \mathrm{p}<0.01 ;{ }^{* * *} \mathrm{p}<0.001$. Data: BHPS 1991-2007. Effect coding.

Note: The model includes the effects of age, social class, gender, education, and housing on the initial partisanship and core values when respondents entered the panel. 